\title{
Snake River: A Navigation and Spawning Dilemma
}

\author{
Kenneth R. Olson ${ }^{(0)}$, Cory D. Suski \\ Department of Natural Resources, College of Agricultural, Consumer, and Environmental Sciences, University of Illinois, \\ Urbana, USA \\ Email: krolson@illinois.edu
}

How to cite this paper: Olson, K.R. and Suski, C.D. (2021) Snake River: A Navigation and Spawning Dilemma. Open Journal of Soil Science, 11, 479-503.

https://doi.org/10.4236/ojss.2021.1110024

Received: September 21, 2021

Accepted: October 17, 2021

Published: October 20, 2021

Copyright (c) 2021 by author(s) and Scientific Research Publishing Inc. This work is licensed under the Creative Commons Attribution International License (CC BY 4.0).

http://creativecommons.org/licenses/by/4.0/

\begin{abstract}
The Snake River in northwestern United States is $1735 \mathrm{~km}$ long, the largest tributary of the Columbia River and is the $13^{\text {th }}$ longest river in the United States. The Snake River drainage basin includes parts of six U.S. states. The Snake River Plain was created by a volcanic hotspot that lies beneath Yellowstone National Park. The previous Ice Age carved out canyons, cliffs and waterfalls along the middle and lower Snake River. The Missoula Flood was to the north and Bonneville Flood to the south altered the Snake River and surrounding landscape. The Snake River has a drainage basin of $282,000 \mathrm{~km}^{2}$ in the states of Oregon, Washington, Utah, Nevada and Idaho. The Snake River drops from mountain elevations of $3000 \mathrm{~m}$ to its confluence with the Columbia River. The river is one of the most biologically diverse freshwater systems in the United States with trails designed to promote recreational tourism, increase use of the Snake River and create generations of people who care about the river and are willing to protect and provide environmental stewardship of the river watershed resources.
\end{abstract}

\section{Keywords}

Bonneville Flood, Hells Canyon, Ice Harbor, Oregon Trail, Shoshone, Snake River Plain, Wheat Growers Association

\section{Introduction}

The Snake River is the largest of the Columbia River tributaries (Figure 1) and (Figure 2). Its headwaters are in the mountains of the Continental Divide near northwestern Wyoming and the southwestern corner of Yellowstone National Park and flows south through Jackson Lake along the eastern base of the Teton Range in Grand Teton National Park [1]. The Snake River enters Idaho via the 


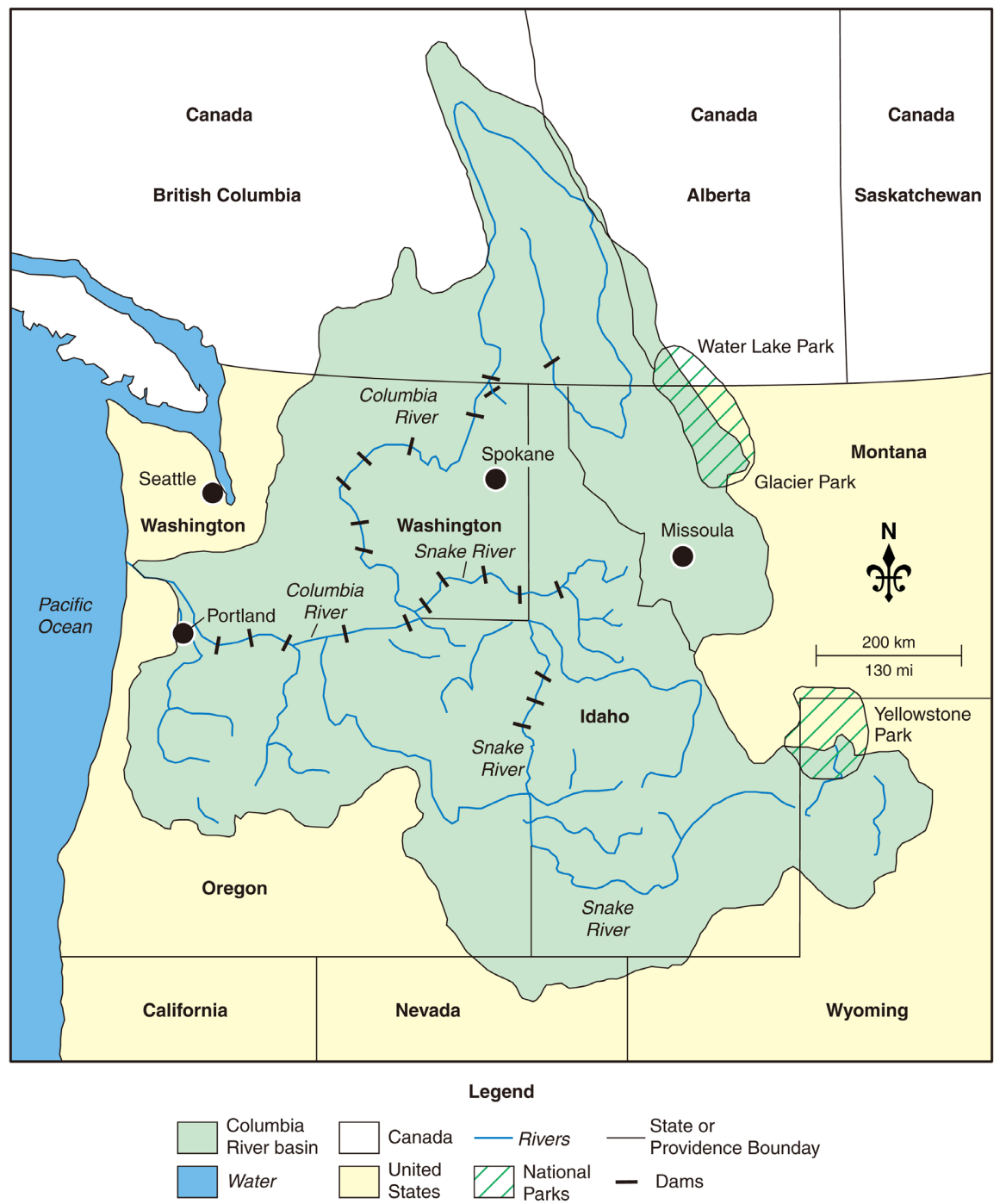

Figure 1. Snake River and Columbia River watershed. Map by Mic Greenberg.

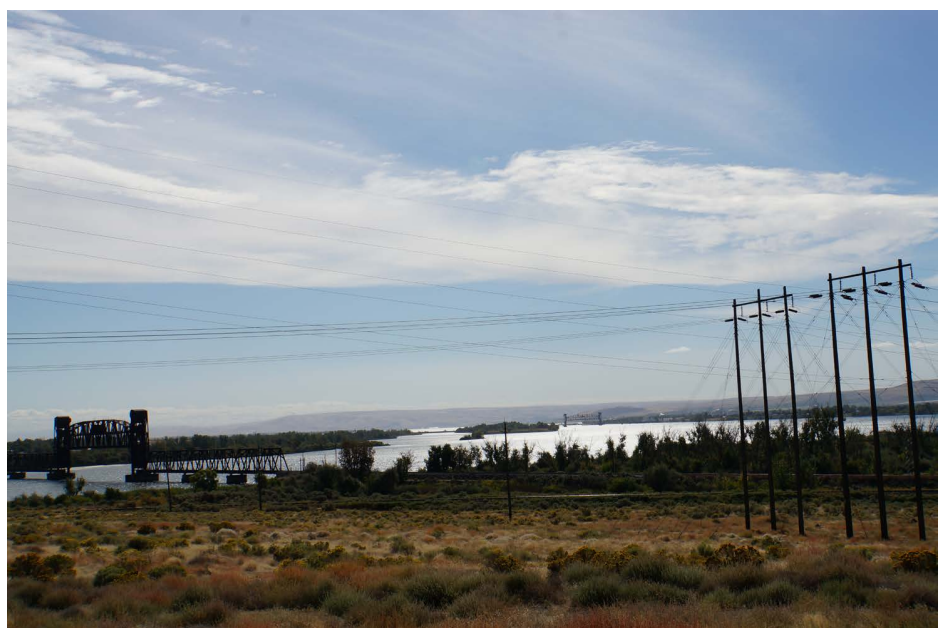

Figure 2. Confluence of the Columbia and Snake Rivers. The upper Columbia River is on the left and the lower Columbia River is on the right. The Snake River is in the middle of the picture coming in from the east. Photograph by Lois Wright Morton. 
Palisades Reservoir. The river leaves the mountains and crosses the broad Snake River Plain (Figure 3) of southern Idaho [2]. At the western edge of Idaho, it joins with Boise River. The Snake River turns north and forms the boundary between Idaho and Washington. At Lewiston, Idaho (Figure 4) the Snake River then turns west to join the Columbia River south of Pasco, Washington.

The primary objective of the study is to document the major Ice Age Flooding events which created the Snake River passageway to the West which permitted United States settlement of the Northwest. The Bonneville Flood, the first of the major Ice Age flooding events eroded soils creating the Snake River Canyon and the widened Hells Canyon. These erosional events created the Snake River and

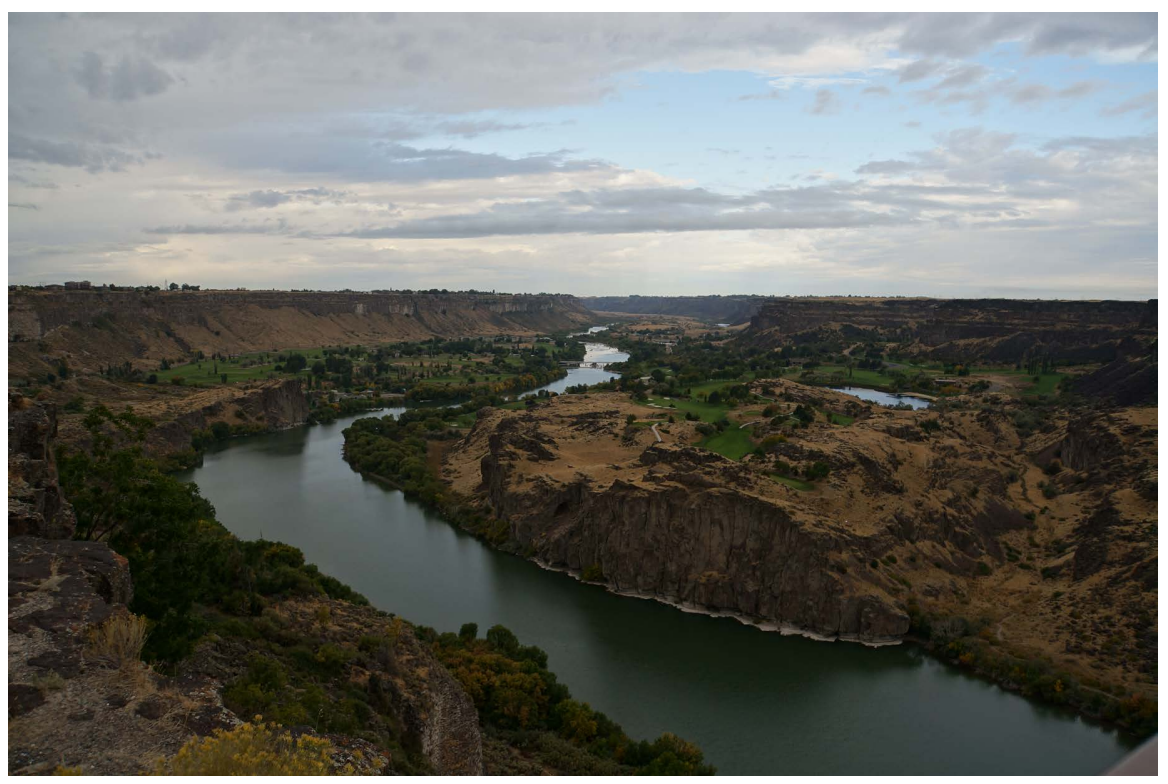

Figure 3. Snake River valley with canon rims carved by Bonneville flood waters and the Snake River.

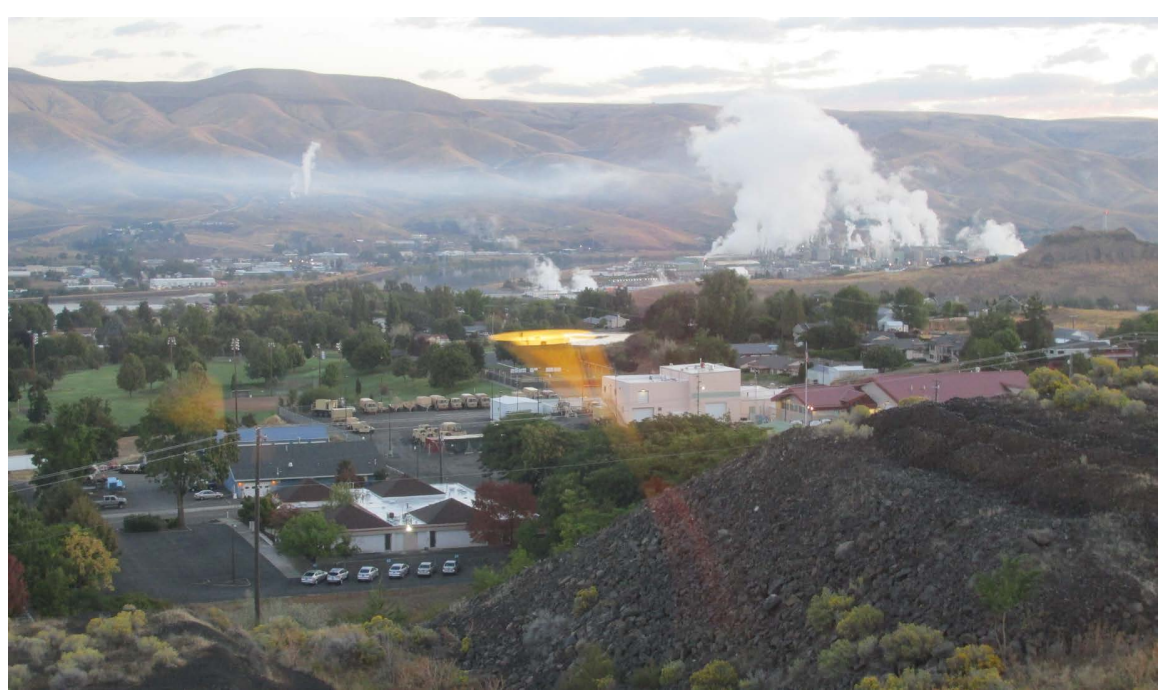

Figure 4. The Snake River valley at Lewiston. Picture taken from the Canyon Rim. 
the passageway to the West. Without this Snake River passageway, the United States settlement of the Northwest would not have happened and the region may have become part of Canada.

\section{Location of Site}

\subsection{Snake River Watershed}

The $279,719 \mathrm{~km}^{2}$ Snake River watershed lies between the Columbia Plateau on the northwest and the Rocky Mountains on the east [3]. The watershed includes parts of Yellowstone National Park (Figures 5-9), Grand Teton National Park,

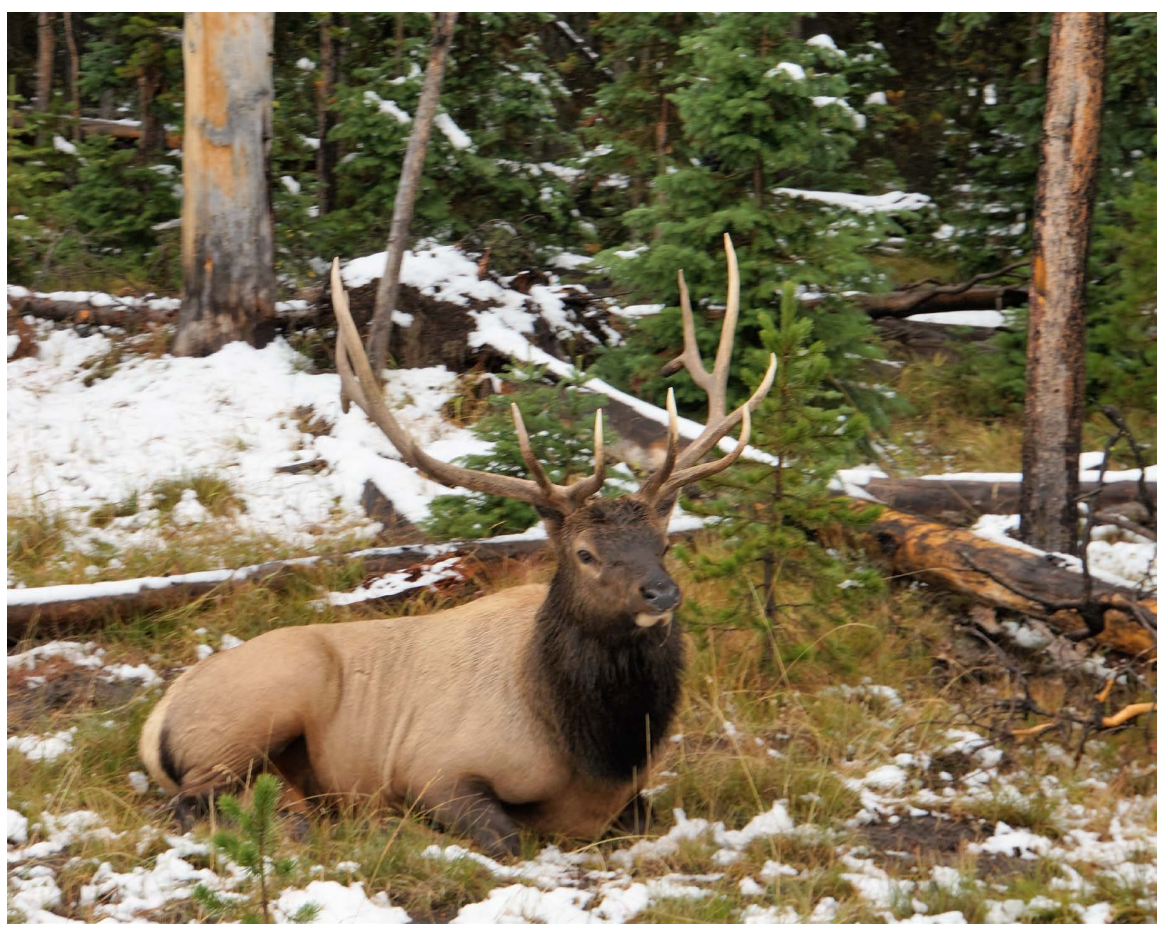

Figure 5. An elk in an early September snow at Yellowstone park.

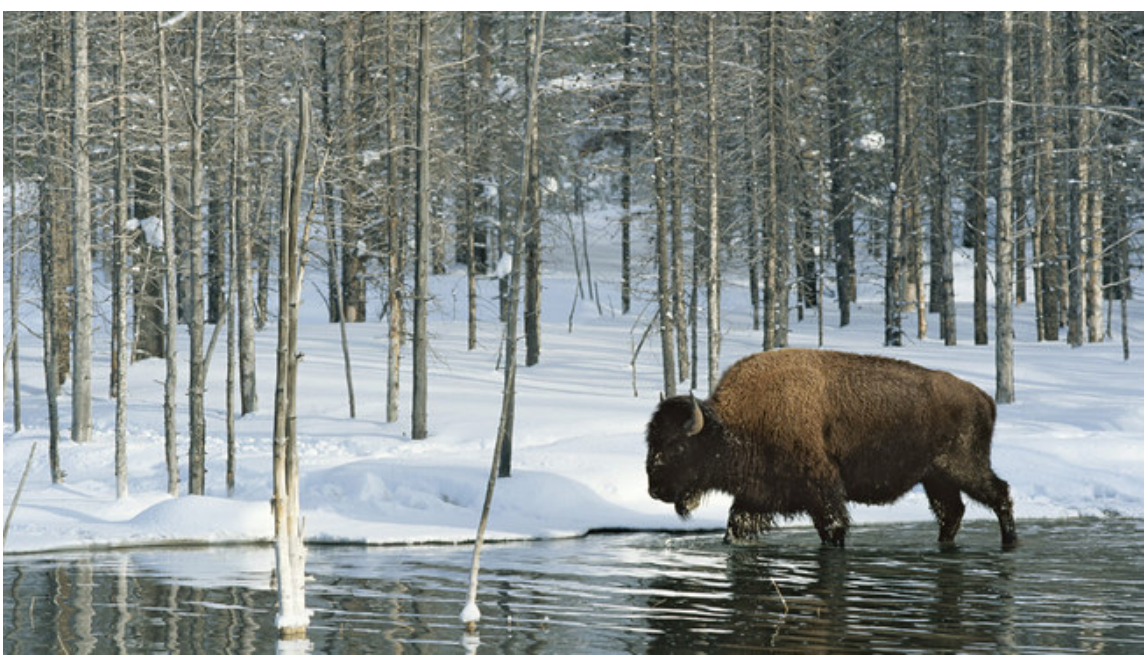

Figure 6. A buffalo crossing a Yellowstone park creek. 


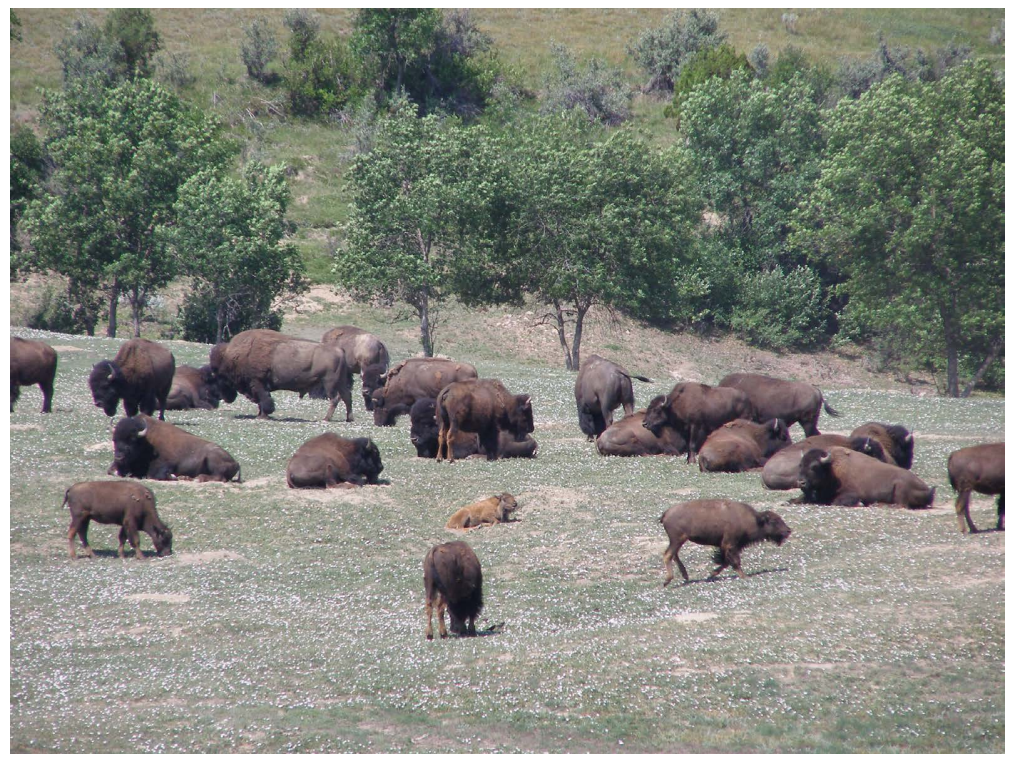

Figure 7. Bison herd on land adjacent to Yellowstone park. Photograph by Lois Wright Morton.

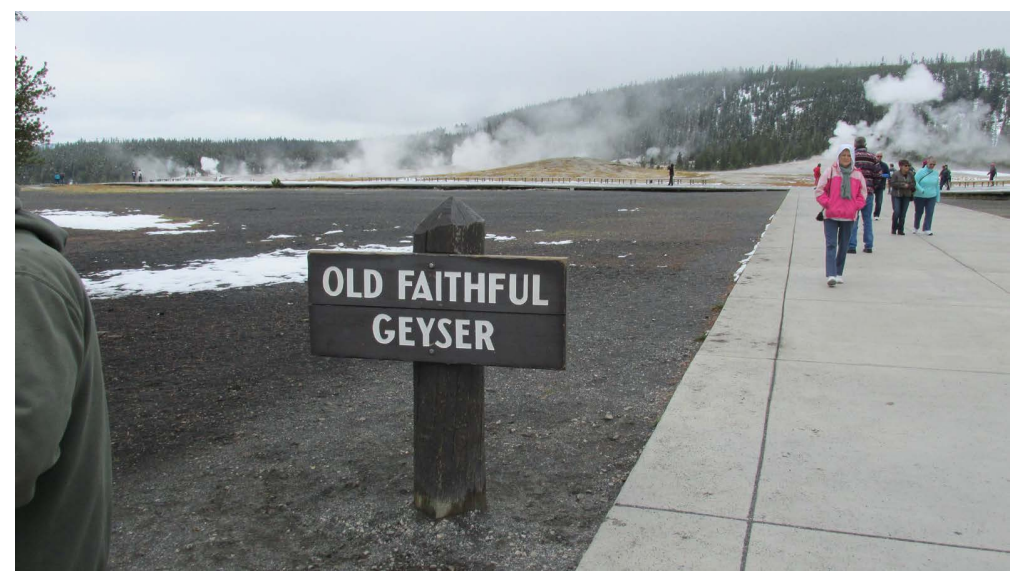

Figure 8. Old faithful geyser sign in Yellowstone park. Photograph by Lois Wright Morton.

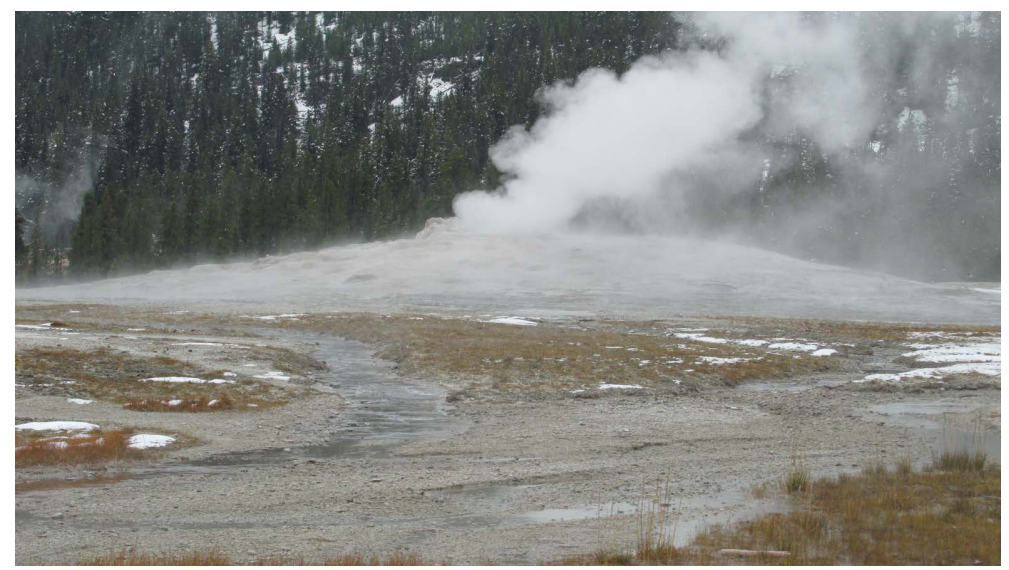

Figure 9. A geyser in Yellowstone park near the headquarters walkway. Photograph by Lois Wright Morton. 
Hells Canyon National Recreation Area (Figure 10) and (Figure 11) and many other state and national parks. The Snake River was the easiest pathway through the Rocky Mountains for the American settlers of the Pacific Northwest (Figure 12). The Oregon Trail followed the Snake River (Figure 13) and (Figure 14) and permitted oxen laden-covered wagons (Figure 15) to link the North Platte River and the Columbia River, and then on to the Willamette Valley [1]. The Snake River was used by Lewis and Clark after they crossed the Rocky Mountains via the Lemhi Pass to get to the Columbia River and the Pacific Ocean. Without the Snake River pathway, American Settlement (Figure 12) would not have occurred in the early 1800s, and much of the Pacific Northwest would have been claimed by the Hudson Bay Company, and potentially may have become part of Canada.

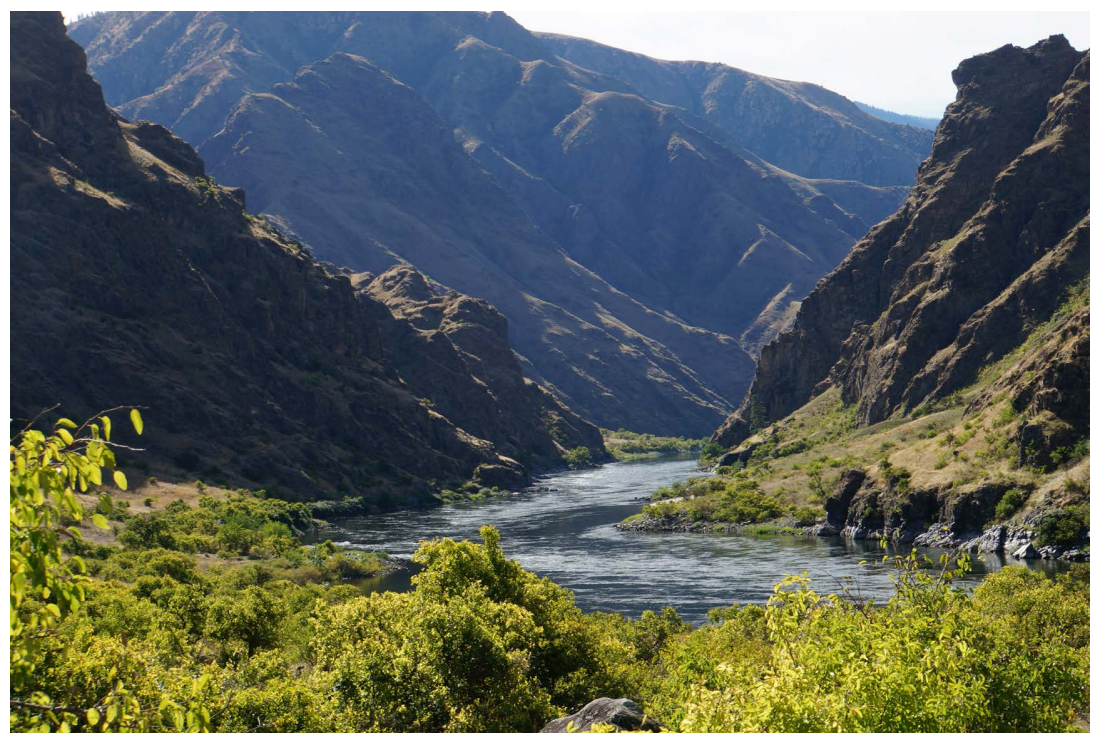

Figure 10. Hells Canyon along the Snake River. Boaters can travel the $50 \mathrm{~km} \mathrm{scenic}$ and wild section of the river.

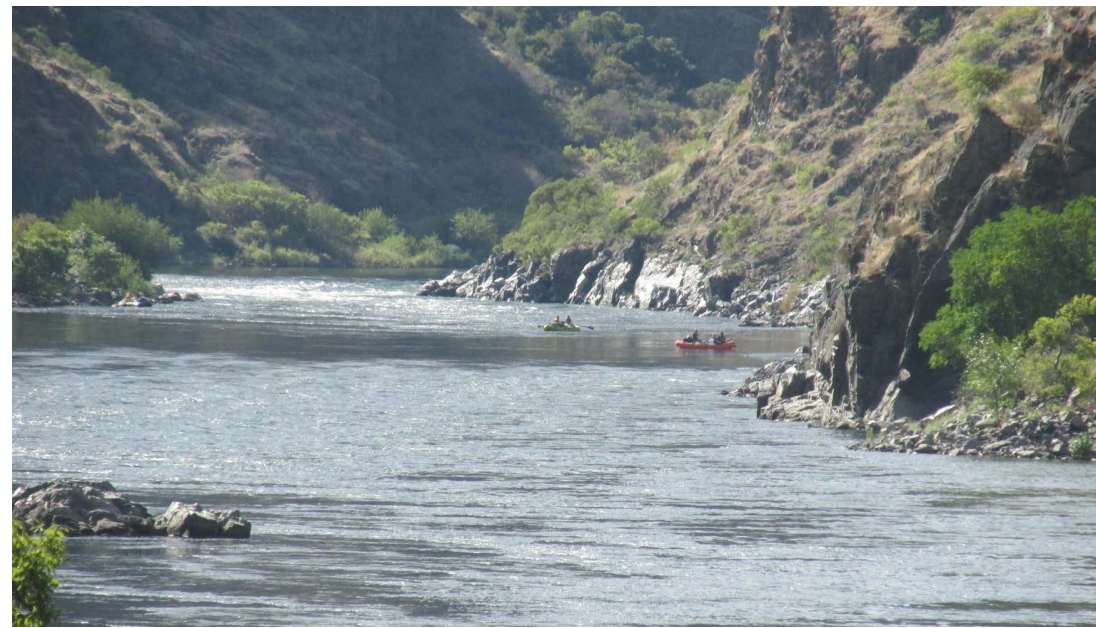

Figure 11. Boating in the forever wild area on the Snake River upriver from Pittsburg landings. 


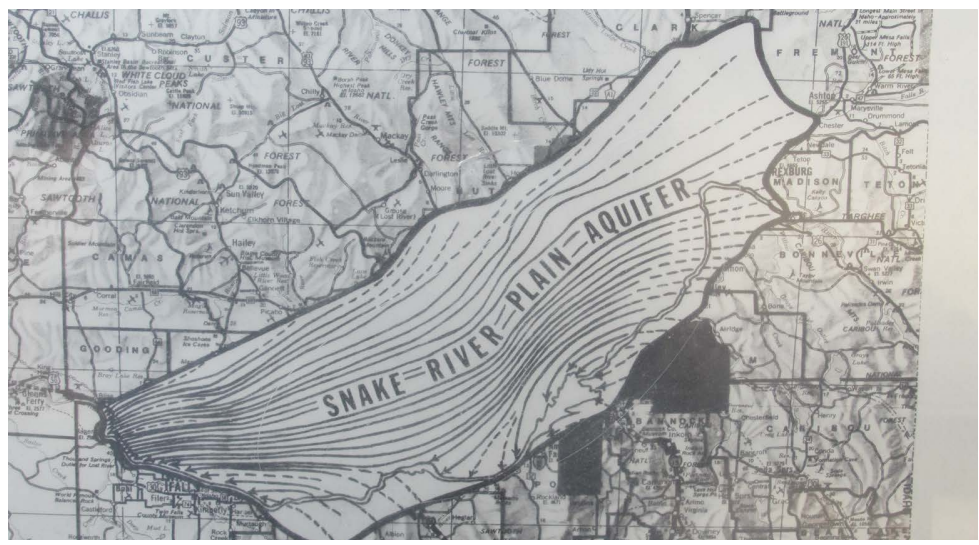

Figure 12. The location of the Snake River plain aquifer overlaying a road map. The Snake River plain was the easiest pathway west through the Rocky Mountains.

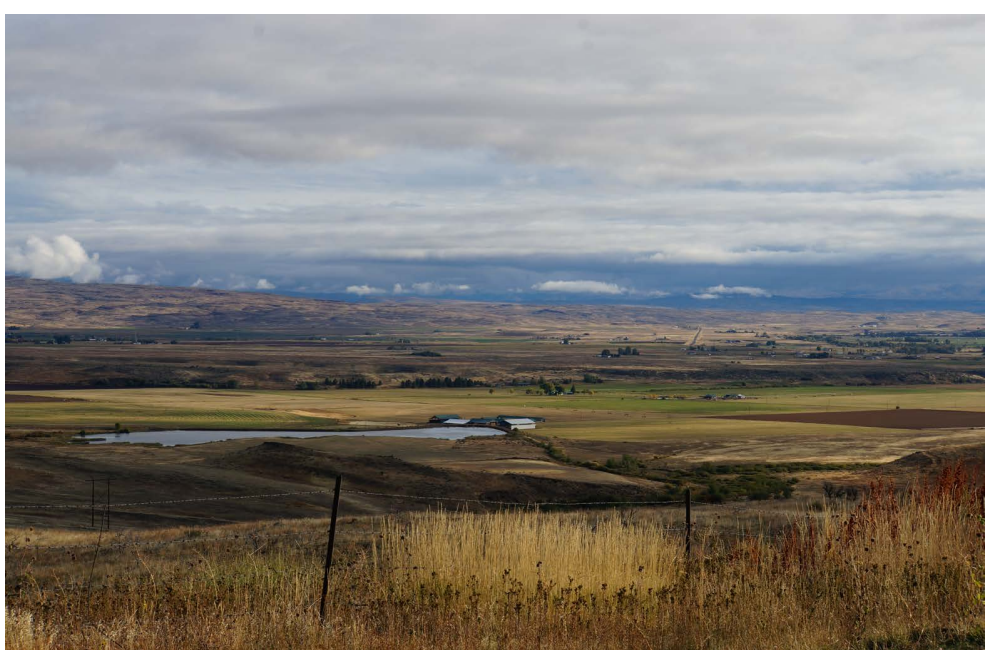

Figure 13. The wide current view of Snake River Plain aquifer. Photograph by Lois Wright Morton.

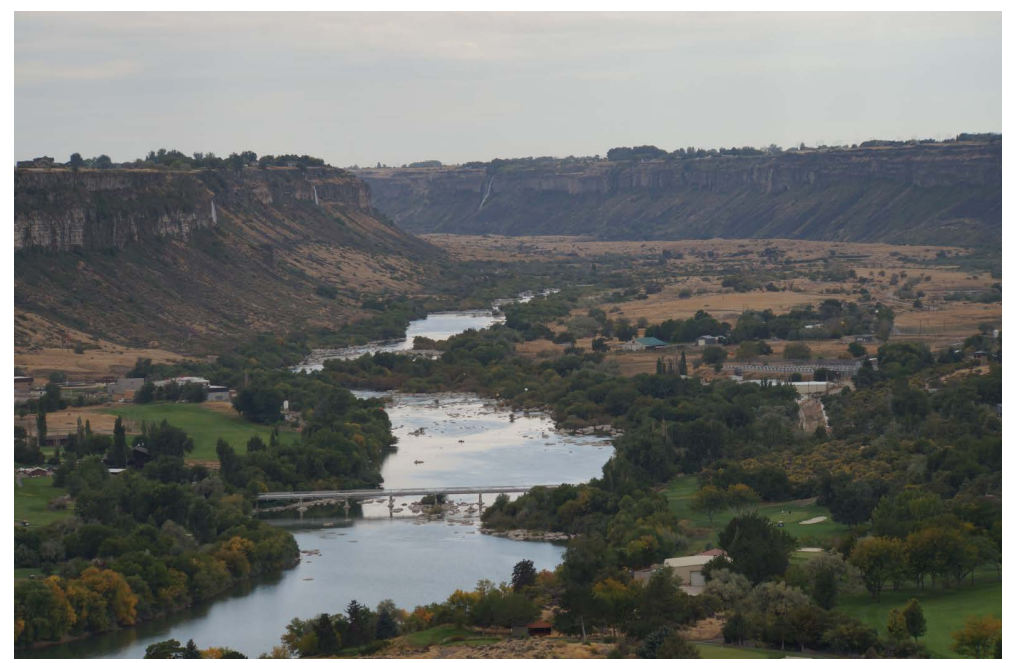

Figure 14. The Snake River Canyon rim, Snake River and Snake River Valley near Evel Knievel jump site. 


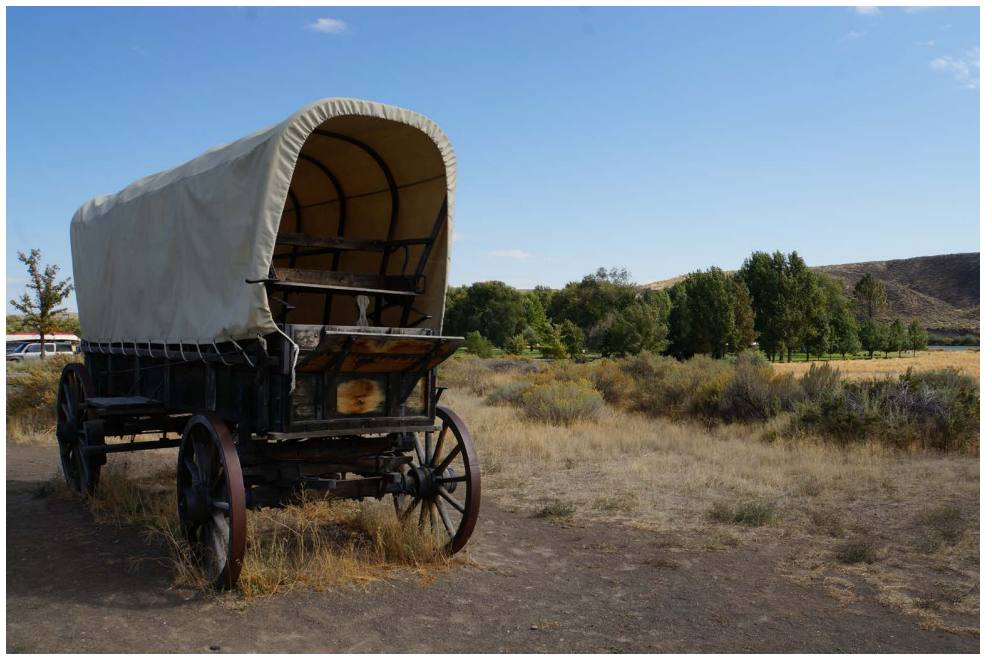

Figure 15. A Conestoga covered wagon at the Oregon Trail Visitor center.

\subsection{Geology of Snake River Basin}

Most of western North America was part of the Pacific Ocean more than 165 million years ago. The subduction of the Farallon Plate underneath the westward-moving North American Plate created the Rocky Mountains [2]. The plates were pushed up by magma trapped between the rising North American Plate and the sinking Farallon Plate. As the North American plate moved westward over the stationary hotspot beneath the Earth's crust, a series of volcanic eruptions and lava flows about 12 million years ago created the Snake River Plain just west of the Continental Divide (Figure 12 and Figure 13).

About 42,000 years ago, lava flowing from Cedar Butte in current southeast Idaho blocked the Snake River at Eagle Rock. A 64 km long American Falls Lake formed behind the lava plug and the lake was stable for 30,000 years. Lake Bonneville formed in the last glacial period (Figure 16), which spilled catastrophically into the Portneuf River and the Snake about 14,500 years ago. This Bonneville Flood (Figure 16) was the first in a series of major Ice Age flooding events in the Northwest (Figure 17).

The Bonneville Flood caused American Falls Lake to breach its natural dam [4]. The floodwaters rapidly eroded the dam and left only the $15 \mathrm{~m}$ American Falls. The flood waters of Lake Bonneville were 20 times the flow of the Columbia River and swept down the Snake River and across the width of southern Idaho. For kilometers on both sides of the Snake River, flood waters scoured the underlying basalt bedrock and eroded the soils forming the Snake River Canyon and creating Carane Falls, Shoshone Falls, Swan Falls, Twin Falls, and others along the Idaho section of the Snake. The Bonneville flood waters continued through Hells Canyon (Figure 18) before reaching the Columbia River. The flood widened Hells Canyon.

The huge amounts of sediment, deposited by the Lake Bonneville Floods in the Snake River Plain, had a lasting effect on the middle Snake River. The Snake River Aquifer (Figure 13) was created by the high hydraulic conductivity of the 


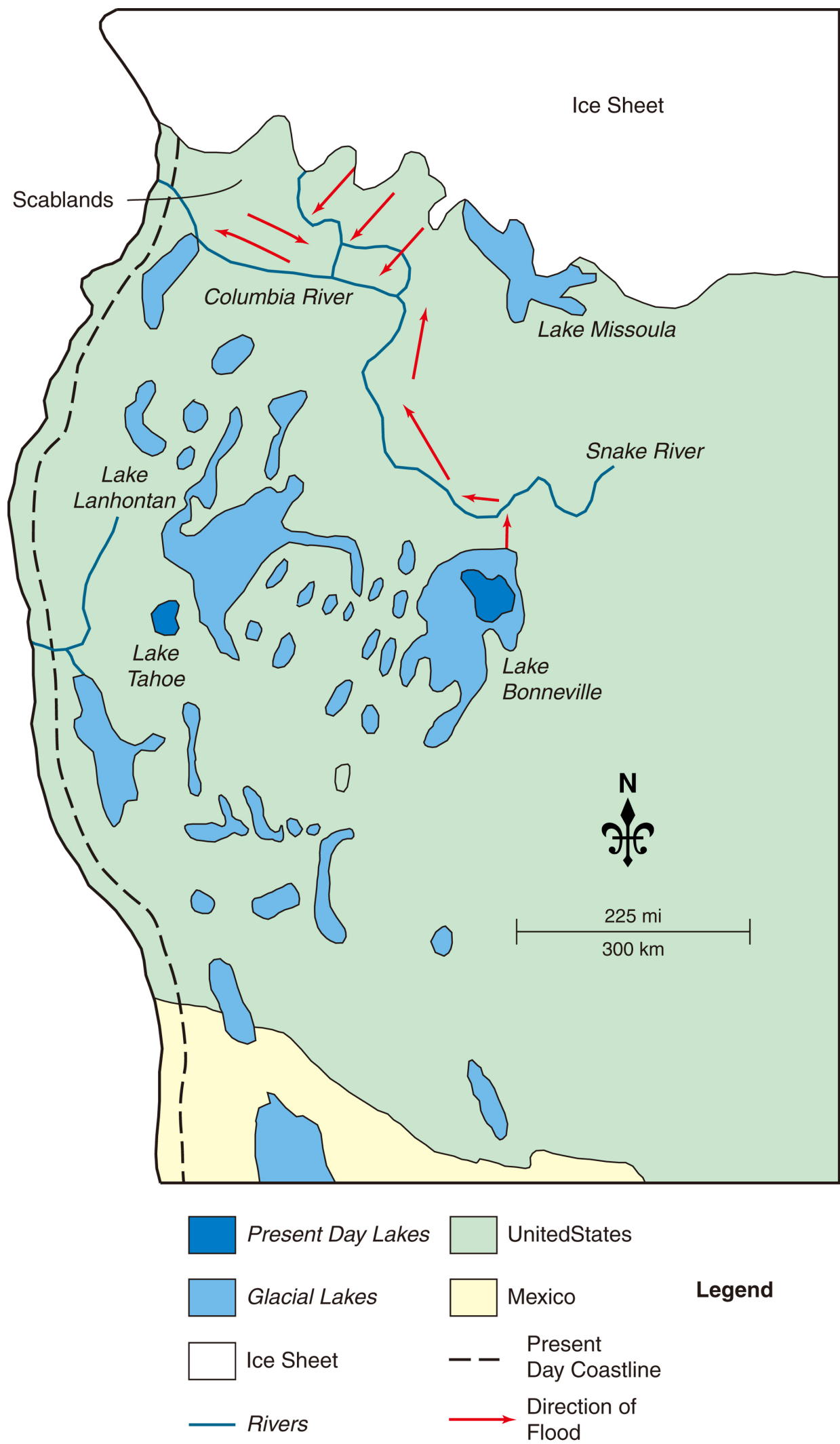

Figure 16. Historical and present day lakes in the western United States. The Bonneville flood drained the historic lake Bonneville through the Snake River to the Columbia River and the Pacific Ocean. Map by Mic Greenberg. 


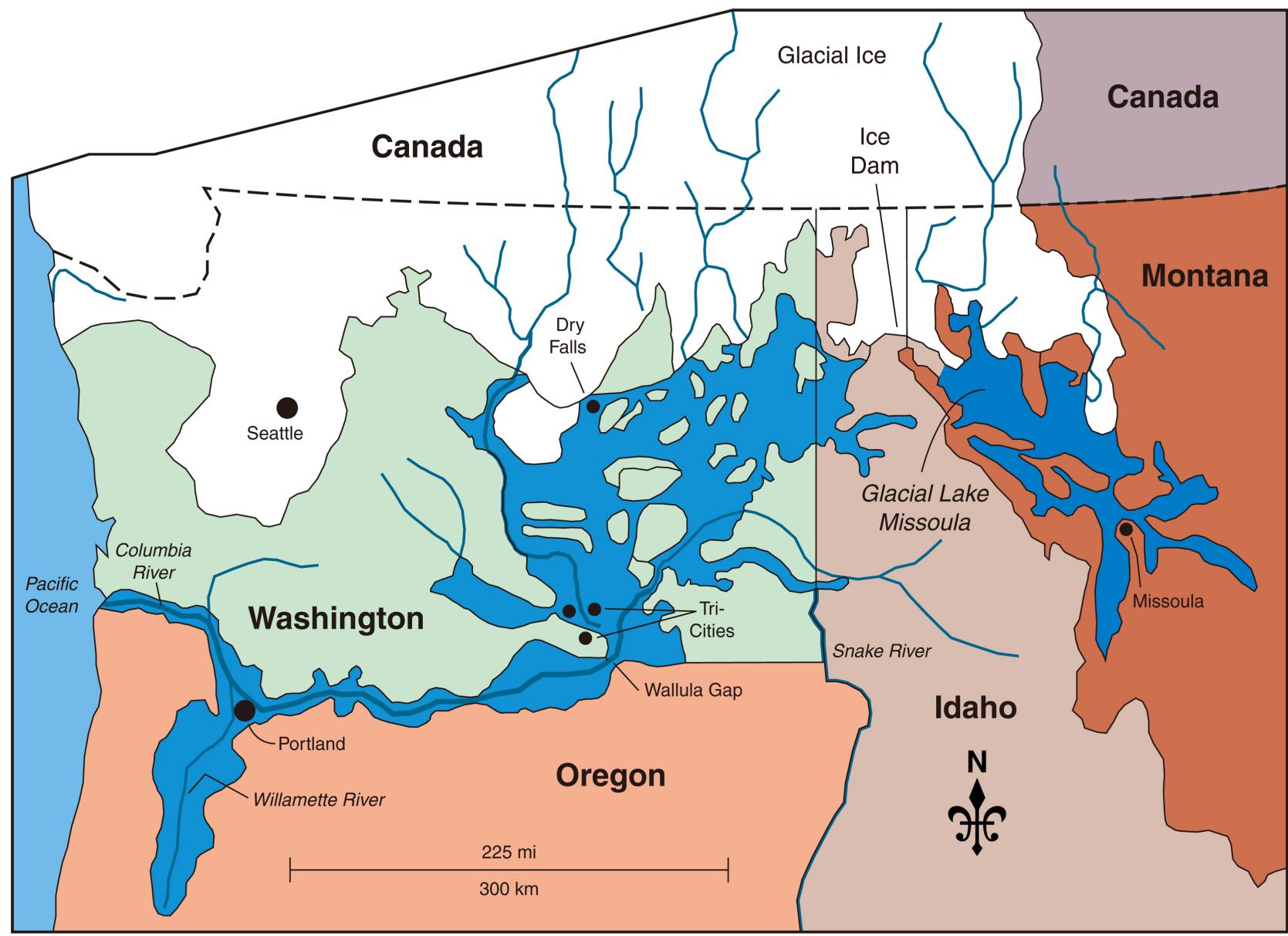

\section{Legend}

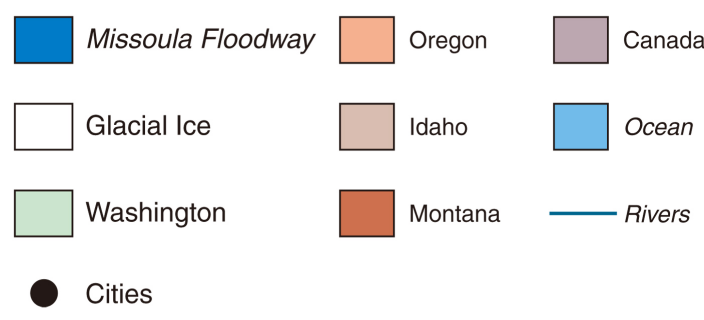

Figure 17. The Missoula floodway pathway from Missoula, Montana to the Pacific Ocean near Portland. Map by Mic Greenberg.

mostly-basaltic rocks in the plain. Instead of flowing into the Snake River the water in many streams and rivers flowing on the north side of the plain disappear into the aquifer. The aquifer currently holds nearly $120 \mathrm{~km}^{3}$ of water underlying $26,000 \mathrm{~km}^{2}$ in a plume $400 \mathrm{~m}$ thick. This water eventually flows into the Snake River via a series of artesian springs.

\subsection{Snake River Basin}

The World Wide Fund (WWF) for Nature [5] divides the Snake River's watershed into two freshwater ecoregions: the "Upper Snake" ecoregion and the "Columbia Unglaciated" ecoregion. Shoshone Falls (Figure 19) has presented a 


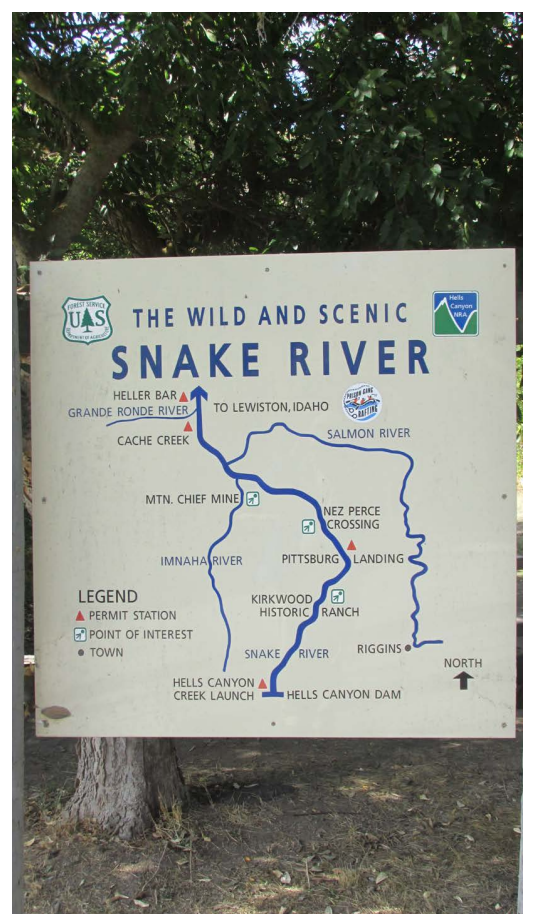

Figure 18. A drawing of the Snake River and tributaries.

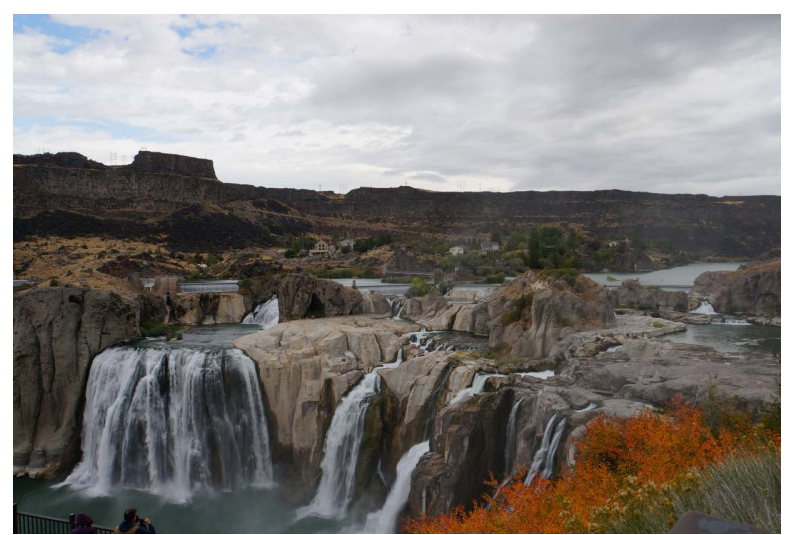

Figure 19. Shoshone Falls in the Snake River Valley. Photograph by Lois Wright Morton.

total barrier to the upstream movement of fish for 30,000 to 60,000 years, and forms the boundary between these two regions. Because the Wood River is biologically distinct from the rest of the downriver Snake the WWF placed the ecoregion boundary about $50 \mathrm{~km}$ downriver from Shoshone Falls to include the Big Wood River in the Upper Snake ecoregion. Only 40\% of the Wood River's fish fauna and $35 \%$ of the fish fauna above the falls are shared with the Lower Snake River (Figure 19). The mostly semi-arid climate of the Snake River watershed receives on average, less than $30 \mathrm{~cm}$ of rainfall per year.

\subsection{Early Inhabitants}

For at least 11,000 years, the Indigenous people have lived along the Snake River. 
In eastern Snake River Plain, there is evidence of Folsom, Clovis, and Plano cultures dating back to at least 10,000 years ago. A vital food supply of the Native Americans who lived along the Snake River and downstream from the Shoshone Falls was salmon and steelhead from the Pacific Ocean and spawned by millions in the river. Historians [4] have divided the time period into three periods: 1) the "Broad Spectrum Foraging" period dating from 11,500 to 4200 years before present, and people during this time period drew on a wide variety of food resources; 2) the "Semi-sedentary Foraging" period from 4200 to 250 years BCE with an increased dependence on fish, especially salmon as well as food preservation and storage; and 3) called the "Equestrian Foragers" period, the 250 to 100 years before present, was characterized by large horse-mounted tribes that spent long periods of time far away from home hunting bison (Figure 7) and (Figure 20).

Two large Native American groups controlled most of the Snake River. The Nez Perce, whose territory stretched from southeastern Columbia Plateau into northern Oregon and western Idaho. Below the Shoshone Fall, the economy and life style centered on salmon that came up the river in enormous numbers. The Shoshone occupied the Snake River Plain both above and below the Shoshone Falls [6] [7]. The Snake River Plain forms one of the relatively easy pathways across the main Rocky Mountains for many hundreds of kilometers (Figure 21). As a result, the Shoshone lifestyle involved a trading dependent economy with Native Americans on both the east and west sides of the Rocky Mountains. The Shoshone were the most powerful tribe in the Rocky Mountain area which extended across the continental divide into the Missouri River watershed. A smallpox epidemic brought on by European fur trappers and explorers was responsible for the death most of the Shoshone east of the Rocky Mountains. Eventually, the Shoshone culture merged with other tribes including the Bannock

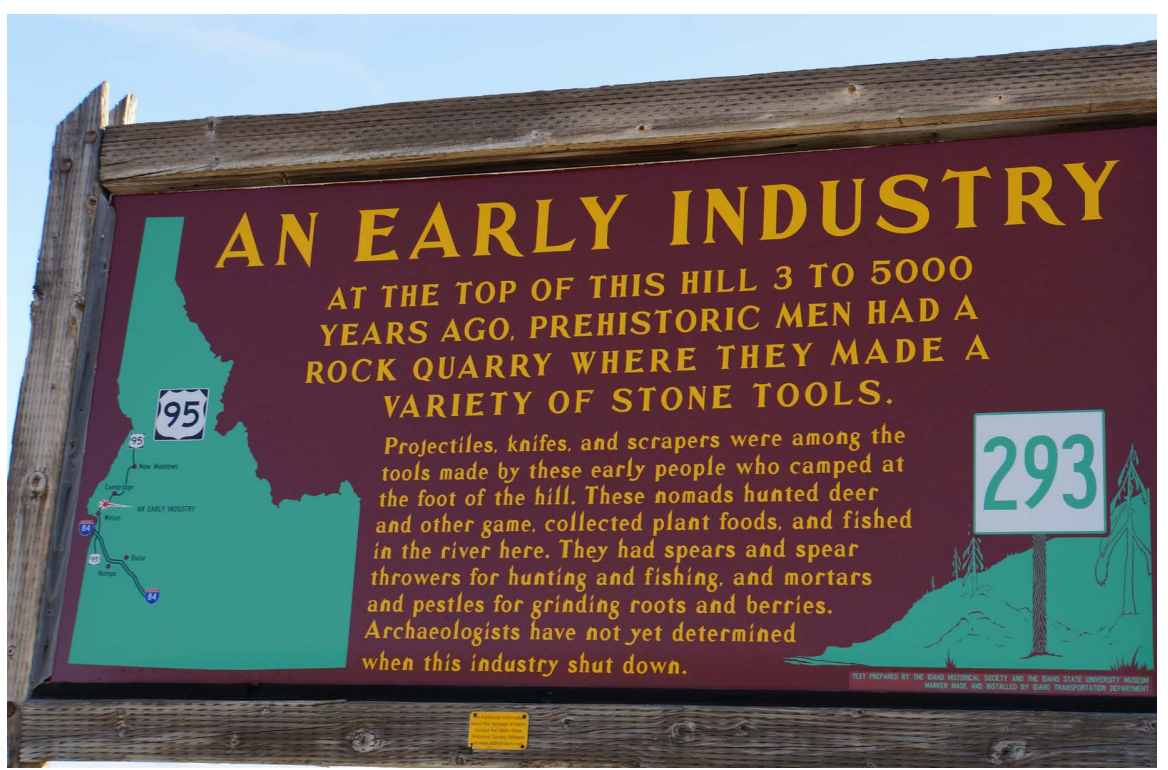

Figure 20. Native American stone tools used in the Snake River Valley. 


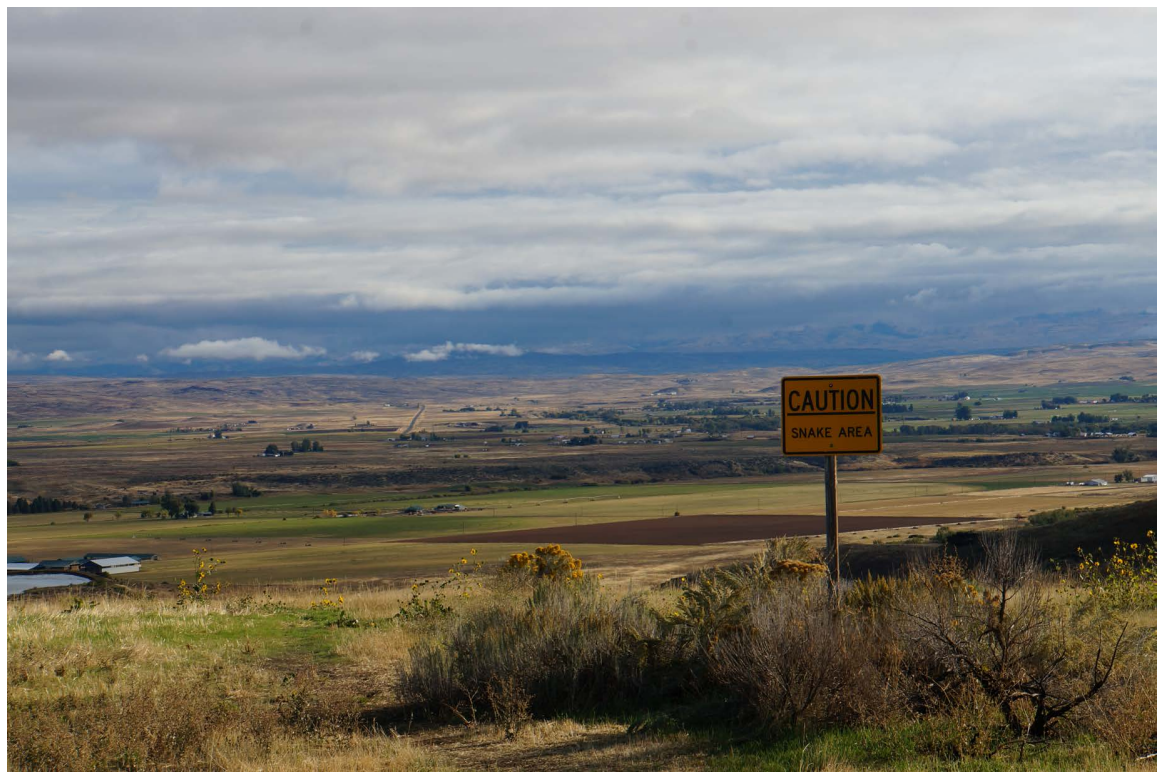

Figure 21. The Snake River plain with a snake warning sign.

who introduced the skill of buffalo hunting on horses, which was acquired from Europeans.

For the people living downstream from Shoshone Falls, salmon and steelhead from the Pacific Ocean spawned by the millions in the river and was a vital food supply. The explorers and fur trappers change the use of the resources of the Snake River basin. By the 1850s the Oregon Trail (Figures 22-24) had become well established bring settlers to the Snake River region. Railroads and steam boats were used to move minerals and agricultural products along the river throughout the $19^{\text {th }}$ and $20^{\text {th }}$ centuries.

\subsection{Horses}

By $1700 \mathrm{CE}$ horses, originally acquired from Spanish in New Mexico and spread widely via native trade networks, reached the Shoshone of the Snake River Plain. The Nez Perce, Flathead and Cayusepeople acquired their first horses around 1730CE. The Nez Perce and Cayuse kept large herds and made annual trips to the Great Plains for bison hunting and adopted the plains culture to a significant extent, and became the main conduit through which horses and the plains culture diffused into the Columbia River region. Along with horses came aspects of the emerging Great Plains culture such as the linking of wealth and prestige to horses and war. Other tribes acquired horses and aspects of the plains culture as well.

\subsection{Exploration and Settling of the Northwestern United States}

The Lewis and Clark Expedition (1805-1806) was the first American group to cross the Rocky Mountains (Figure 25) the hard way and travel down the Snake and Columbia rivers to the Pacific Ocean [8]. The party crossed the Lemhi Pass, a few kilometers from present-day Salmon, Idaho. The party was the first Europeans 


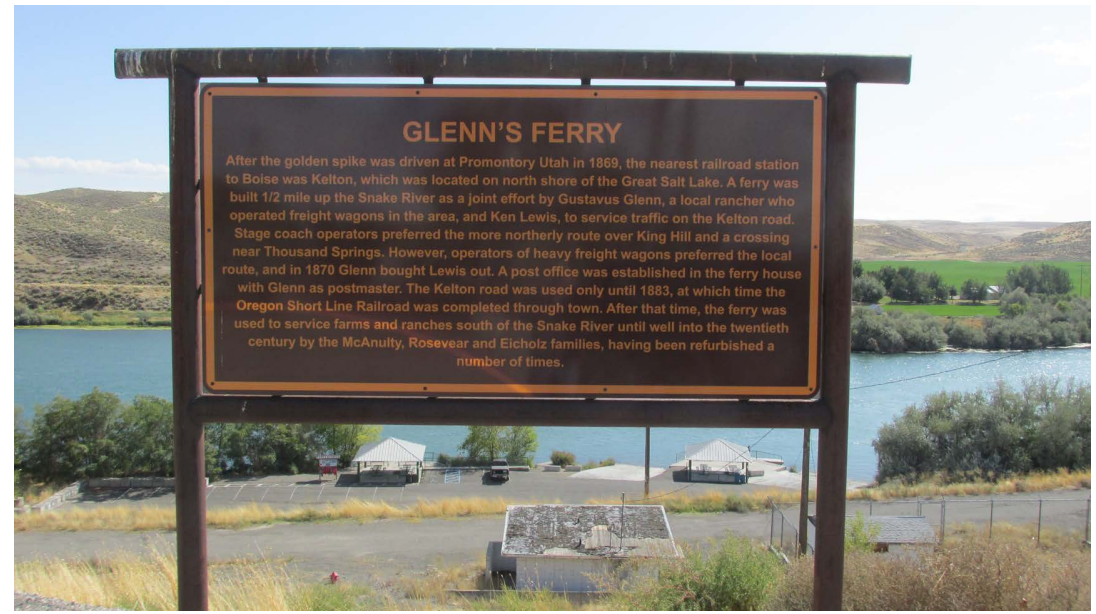

Figure 22. Glenn's ferry crossing of the Snake River. Photograph by Lois Wright Morton.

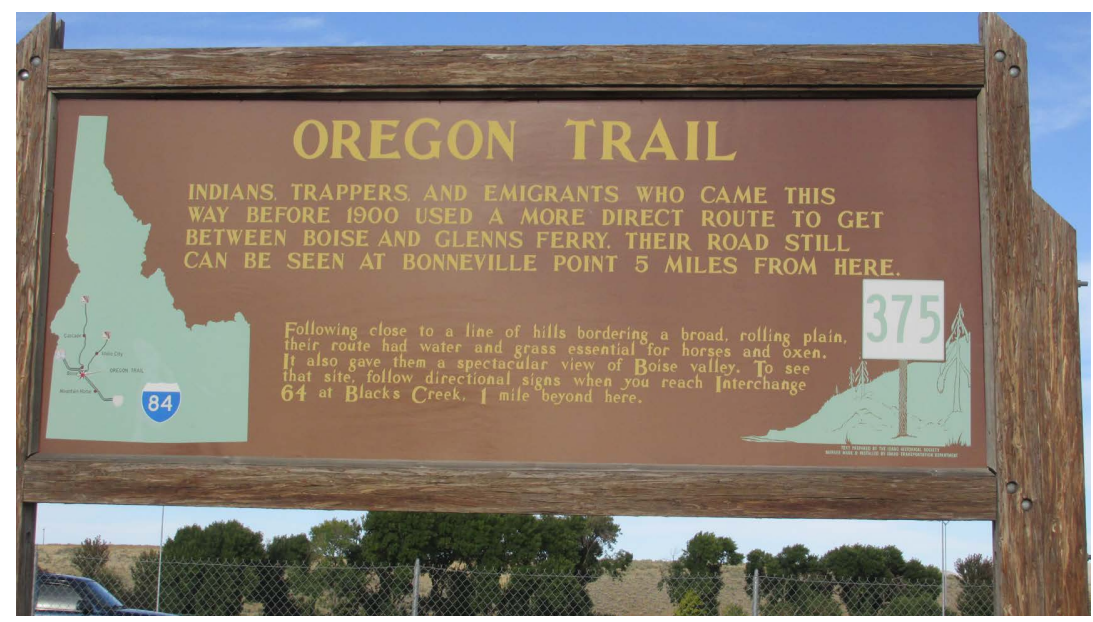

Figure 23. Oregon Trail sign along the Snake River.

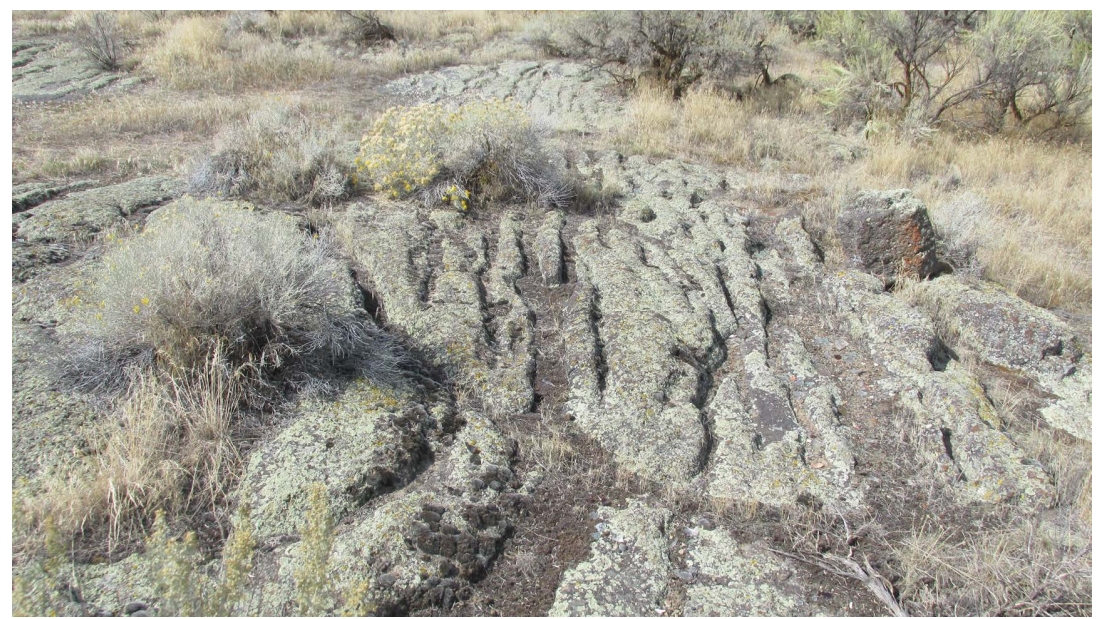

Figure 24. Oregon Trail wheel tracks cut into bedrock exposed at surface. The groves have been weathered and are now moss covered where exposed at the surface. Coestoga covered wagon steel rims cut into the bedrock and left groves that are still visible over 100 years later. Photograph by Lois Wright Morton. 


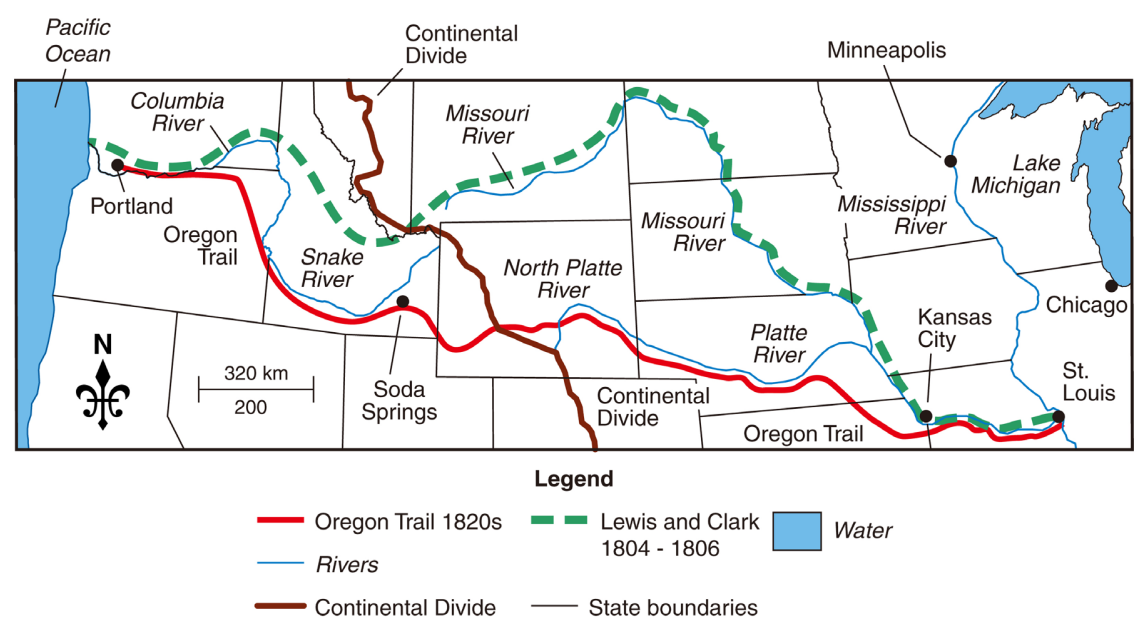

Figure 25. Oregon Trail and Lewis and Clark route to Pacific Ocean from St. Louis, Missouri. Map by Mic Greenberg.

to view the Snake River Watershed (Figure 1). They traveled north on the Lemhi River and attempted to descend into the Snake River but found it impassable because of violent rapids. They then traveled north to the Lochsa River via the Clearwater River into the Snake River and eventually the Columbia River to the Pacific Ocean (Figure 25). After Lewis and Clark returned to Washington, DC and told their story, more American explorers traveled to, and through, the Snake River area and its major tributaries between 1806 and 1811. Many of the later explorers were from the original Lewis and Clark Expedition. Eventually the American fur trappers came looking for beaver streams. However, the Hudson's Bay Company sent Canadian fur trappers into the Snake River watershed in 1819 to kill as many beavers as possible to discourage American trappers from coming to the Oregon territory which included the future states of Oregon, Washington, Idaho and parts of Wyoming and Montana (Figure 1). However, the area was eventually annexed by United States.

\subsection{Oregon Trail the Settlement Pathway to Northwest United States}

By the middle of the $19^{\text {th }}$ century, the Oregon Trail had been established and generally followed along the Snake River. However, settlers had to cross the Snake River when on the Oregon Trail. One ferry crossing was near present day Glenn's Ferry (Figure 22 and Figure 23), and several years later, another ferry crossing of the Snake River was created near the mouth of the Boise River called "Two Island Crossing" or "Three Island Crossing". This area had two and sometimes three islands which split the river into 3 or 4 channels each about $61 \mathrm{~m}$ wide. Emigrants often forded the Snake and proceed down the west side and re-crossed the river near Fort Boise before entering into Hells Canyon gorge. The Lower Snake River flows through a $1.6 \mathrm{~km}$ deep gorge known as Hells Canyon (Figure 10), which is the deepest river gorge in North America. Settlers would continue down the drier east side of the gorge. Some floated the Snake 
and Columbia River to the Willamette River and valley (Figure 26), often referred to as the "Land of Flowing Milk and Honey", and the destination of choice for the travelers on the Oregon Trail [1].

\subsection{Steamboat Navigation on the Snake River}

The Snake River was far more difficult for steamboats to navigate than the Columbia River [9]. The $320 \mathrm{~km}$ Snake drops over $2600 \mathrm{~m}$ in elevation. From the 1860 s to the 1940s, steamboats traveled the Snake River from the confluence with the Columbia River to near the confluence with the Imnaha River just below Hells Canyon. Most of the steamboats stopped at Lewiston (Figure 1), located at the confluence of the Clearwater and Snake rivers. This section was the easiest to navigate, but there were still over 60 sets of rapids to traverse.

Freight and passenger service to Lewiston lasted until the late $19^{\text {th }}$ century and the introduction of railroads in the grain-growing region of the Palouse Hills. Lewiston is located $230 \mathrm{~km}$ up river from the confluence of the Snake and the Columbia, and $748 \mathrm{~km}$ from the mouth of the Columbia where the river drains into the Pacific Ocean. At Fort Boise in 1866, the Oregon Steam Navigation (OSN) Company launched the Shoshone boat, which provided passenger and freight service on the upper Snake for the Owyhee and Boise mines.

\subsection{Animal and Plant in the Snake River Valley}

In addition to aquatic species, much of the Snake River watershed supports large animals including numerous species of birds, mammals, reptiles and amphibians. Pronghorn (Antilocapra americana) and bighorn sheep (Ovis canadensis) are common in the area drained by the "lost streams of Idaho". These large creeks and rivers that flowed from the Rocky Mountains south disappeared into

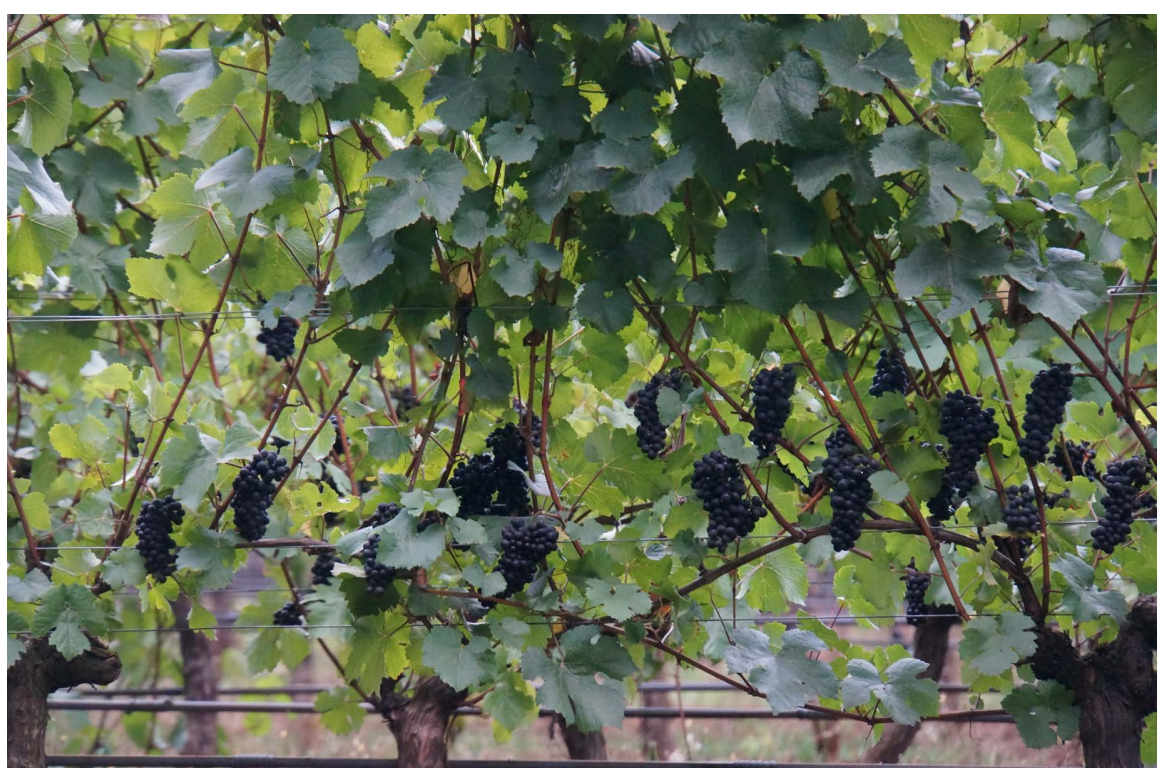

Figure 26. Noir grapes growing in the Willamette Valley south of Portland, Oregon. Photograph by Lois Wright Morton. 
the Snake River Aquifer.

The Snake Riverhead waters, inside protected areas, remain heavily forested. The Snake River watershed includes a diversity of vegetation zones both past and present. A majority of the watershed was once covered with shrub-steppe grassland. Along the length of the Snake River and its tributaries there are riparian zones, wetlands and marshes. At higher elevations, conifer (Pinophyta spp.) forests, of which ponderosa pine (Pinus ponderosa) is most common, dominate the landscape. The basin ranges from alpine to semi-desert climates, providing habitat for hundreds of species of plants. In southeastern Washington, the lowermost part of the watershed is now mostly occupied by irrigated farms. The rest of the Plateau area is characterized by dry lakes, low hills, and an arid, borderline desert, climate.

\subsection{Hiking Trails in Snake River Canyon}

The $330 \mathrm{~km}$ Idaho-Oregon Snake trail runs along the Snake River in Eastern Oregon and Southwest Idaho. This trail ends at Farewell Bend State Park, Oregon and begins at Two Island Crossing State Park, Idaho. Hells Canyon [3] provides the ultimate back packing experience. Due to rattlesnakes, poison ivy and the fact that the rim is thousands of meters above the canyon floor, there is a serious risk of a sore neck from the amount of time spent looking both upward and downward while hiking.

After Evel Knievel attempted to jump the Snake River canyon (Figure 18, Figure 27 and Figure 28) on a rock-powered motorcycle, he became a local, national and international legend and the local visitor center has an exhibit featuring Evel Knievel's jump; an improved road is being built to the jump site. The jump failed and he had to parachute safely to the valley floor. Two Island Crossing (Figure 29) and (Figure 30) has an Oregon Trail History and Education Center with self-guided tours and group educational tours.

\subsection{Salmon and Other Anadromous Fishes in Snake River}

Before European settlement, the Snake River was one of the most significant rivers for the spawning of anadromous fishes that are hatched in the headwaters of rivers, live in the ocean, and return to spawn in the river. The river supported species including chinook salmon (Oncorhynchus tshawytscha), coho salmon (Oncorhynchus kisutch), and sockeye salmon (Oncorhynchus nerka), as well as steelhead (Oncorhynchus mykiss), white sturgeon (Acipenser transmontanus), and Pacific lamprey (Entosphenus tridentatus). It is known that before the construction of dams on the Snake River, there was a sockeye salmon run was about 150,000 and three major chinook salmon runs in the river totaling about 120,000. The historical barrier to fish migration on the Snake River was Shoshone Falls, a waterfall in the Snake River Plain.

\subsection{Lower Snake River Dams}

Starting in 1890s, 15 major dams were built on the Snake River to generate 


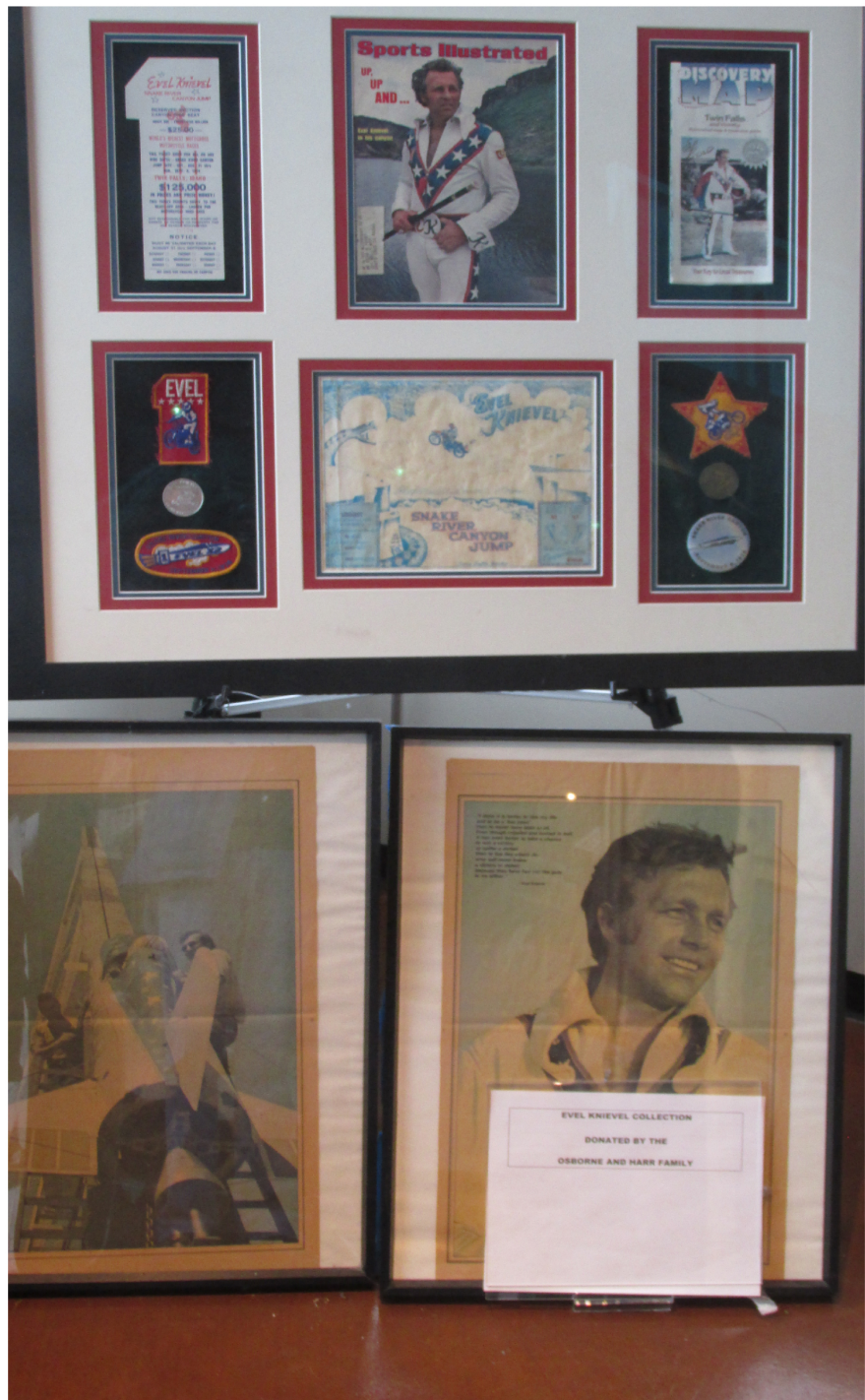

Figure 27. Evel Knievel exhibit at the Snake River visitor center.

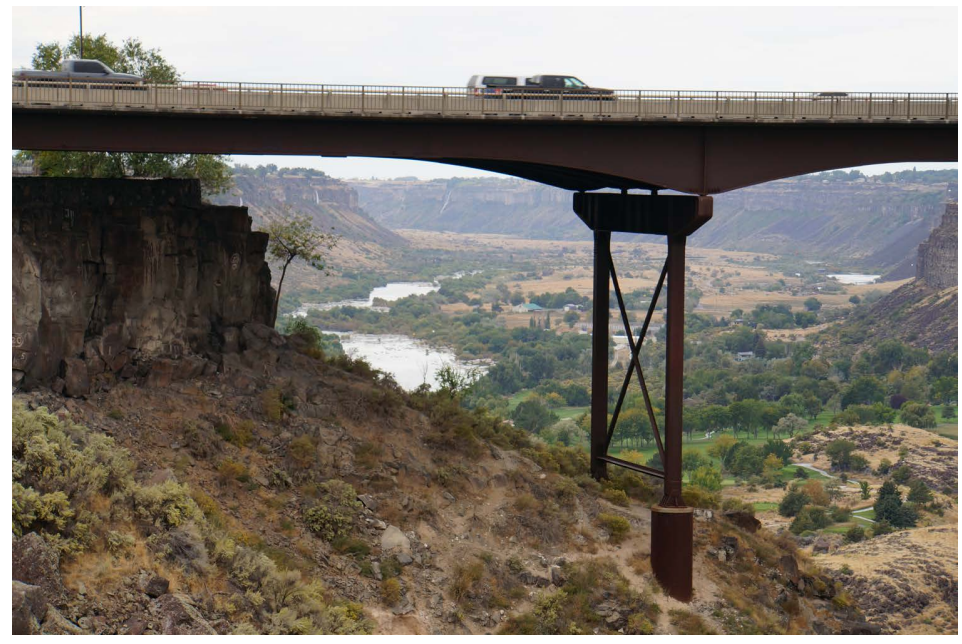

Figure 28. A highway bridge extending from rim to rim across the Snake River Canyon and the Snake River. Photograph by Lois Wright Morton. 


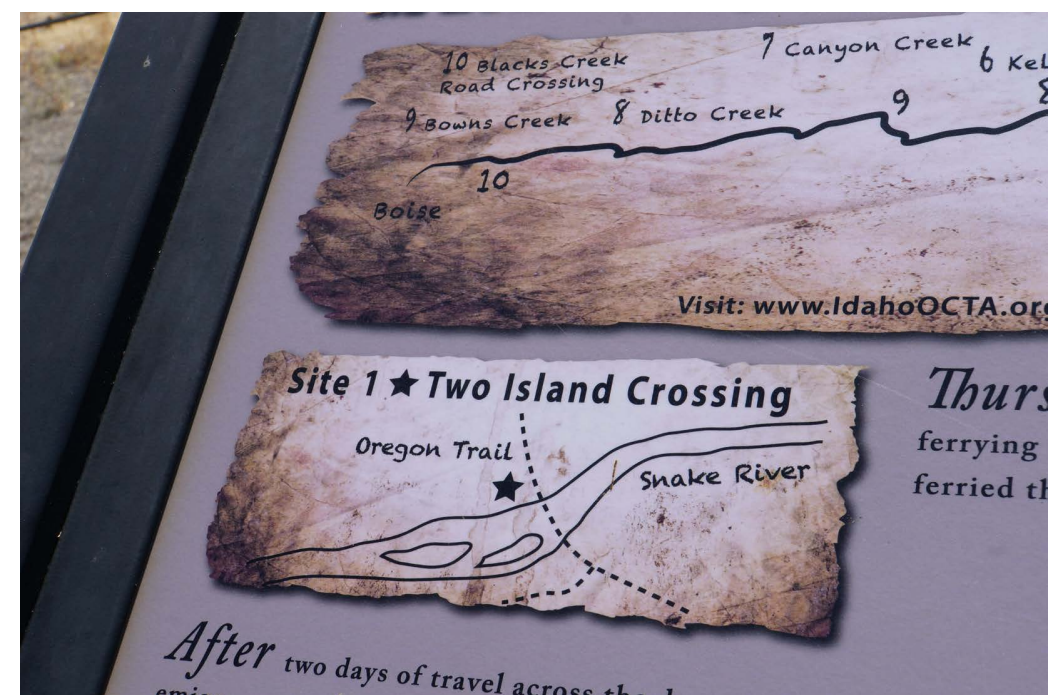

Figure 29. The original two island crossing sign displayed at the Oregon trail history and education center.

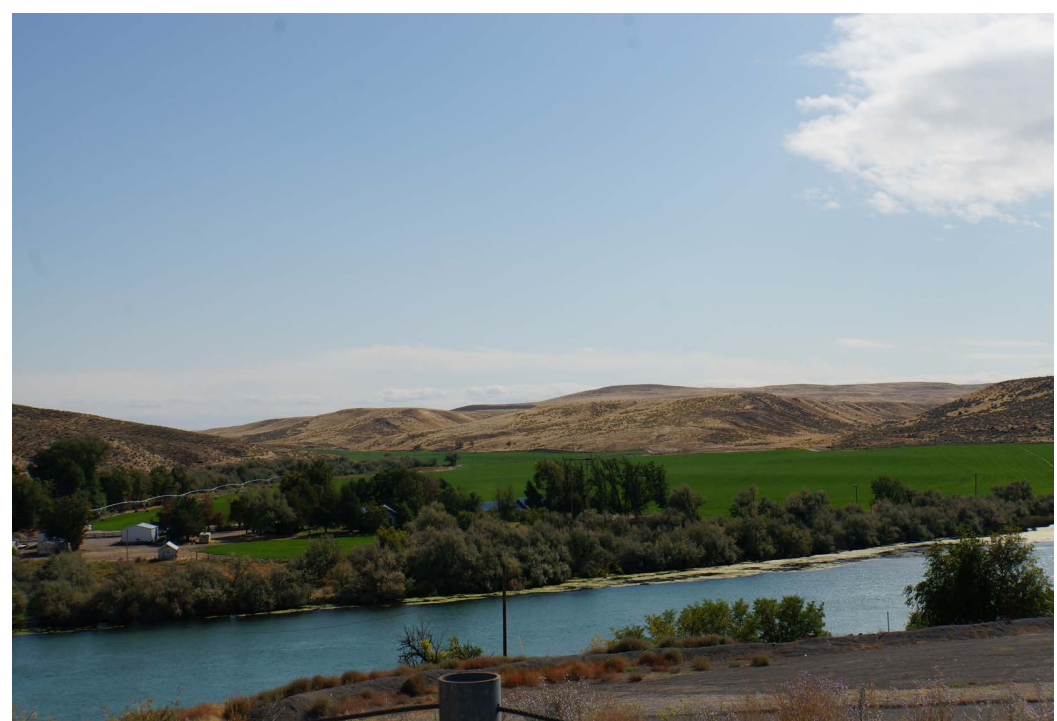

Figure 30. The Snake River near the Oregon trail Two Island crossing.

hydroelectricity, provide irrigation water and improve navigation. Four more dams on Lower Snake provide large navigation locks and all are equipped with fish passage facilities (Figure 31) and (Figure 32). These dams blocked salmon migration into Hells Canyon. Removal of several dams on the lower Snake River has been proposed to restore some of the river's once-great salmon runs. The dams have also affected water quality and created other environmental issues. The Upper Snake River in Idaho is used for irrigation and hydropower (Figure 33) and (Figure 34). The main stream is regulated by several reservoirs and dams, the most expansive being American Fall Dam and Reservoir.

Much of the bottomland along the Snake River, is irrigated farmland (Figure 35) and (Figure 36), especially in the lower and middle sections. Irrigation dams include American Falls Dam, Minidoka Dam and C.J. Strike Dam. Additional 


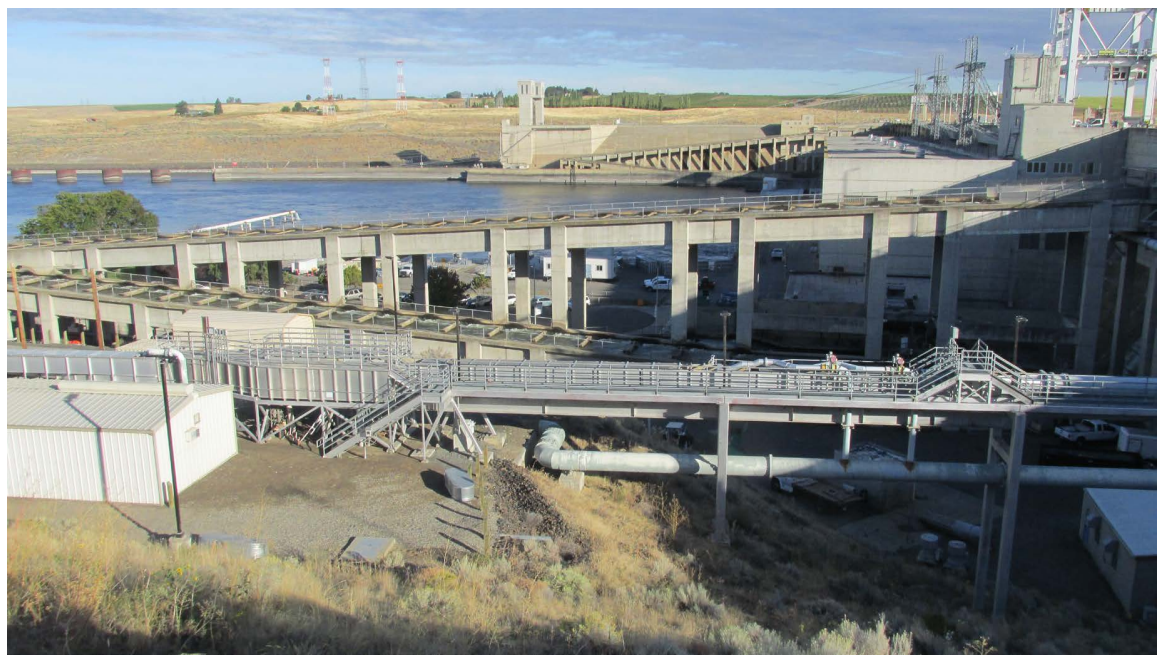

Figure 31. The fish latter at the Ice Harbor lock and dam on the Snake River just east of the confluence of the Columbia and Snake rivers. The fish latter fish population is monitored and counted 16 hours a day. Photograph by Lois Wright Morton.

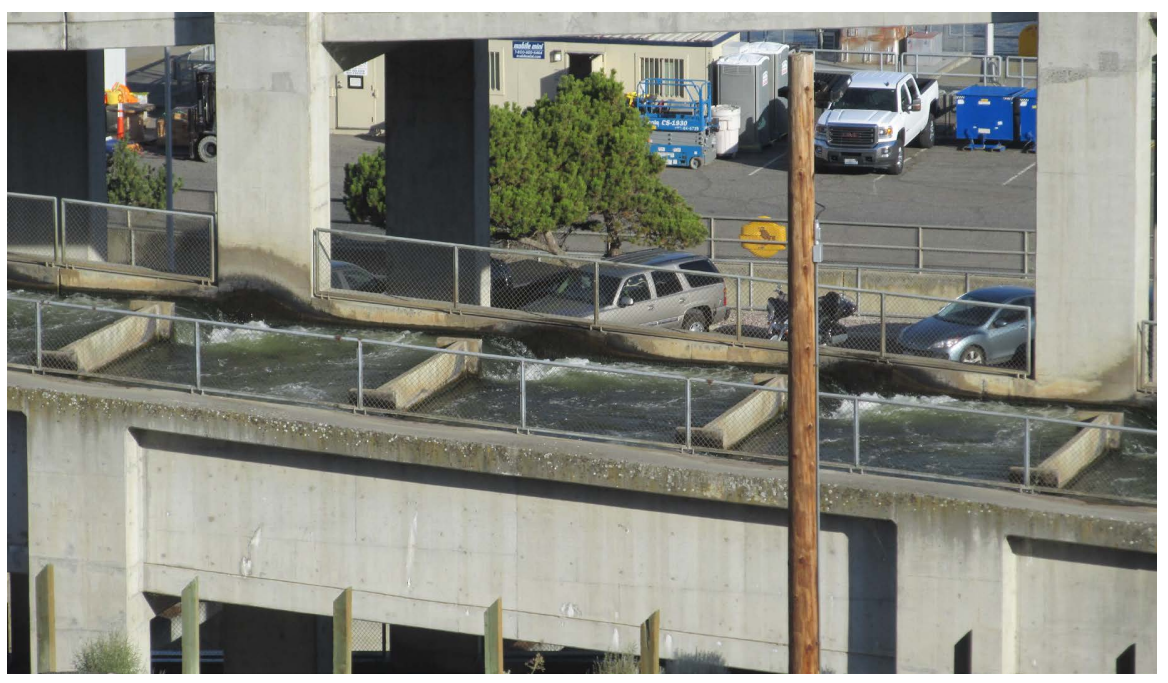

Figure 32. A close-up of the fish latter at the Ice Harbor lock and dam on the Snake River just east of the confluence of the Columbia and Snake rivers. Photograph by Lois Wright Morton.

water for irrigation is pumped from the Snake River Aquifer. In 1976, the Teton Dam collapsed flooding the Upper Snake River valley. In addition to irrigation, many produce electricity, provide navigation channel and flood control. The fish passage is limited to a stretch of the Snake down river from Hells Canyon (Figure 11).

\subsection{Lower Snake River Dam Removal Proposal}

A controversy has erupted since the late 20th century over the four lower Snake River dams. The primary reason being that removing the dams would allow anadromous fish to reach the lower Snake River tributaries and spawn [10]. Some agricultural groups in the Pacific Northwest have fiercely opposed removing 


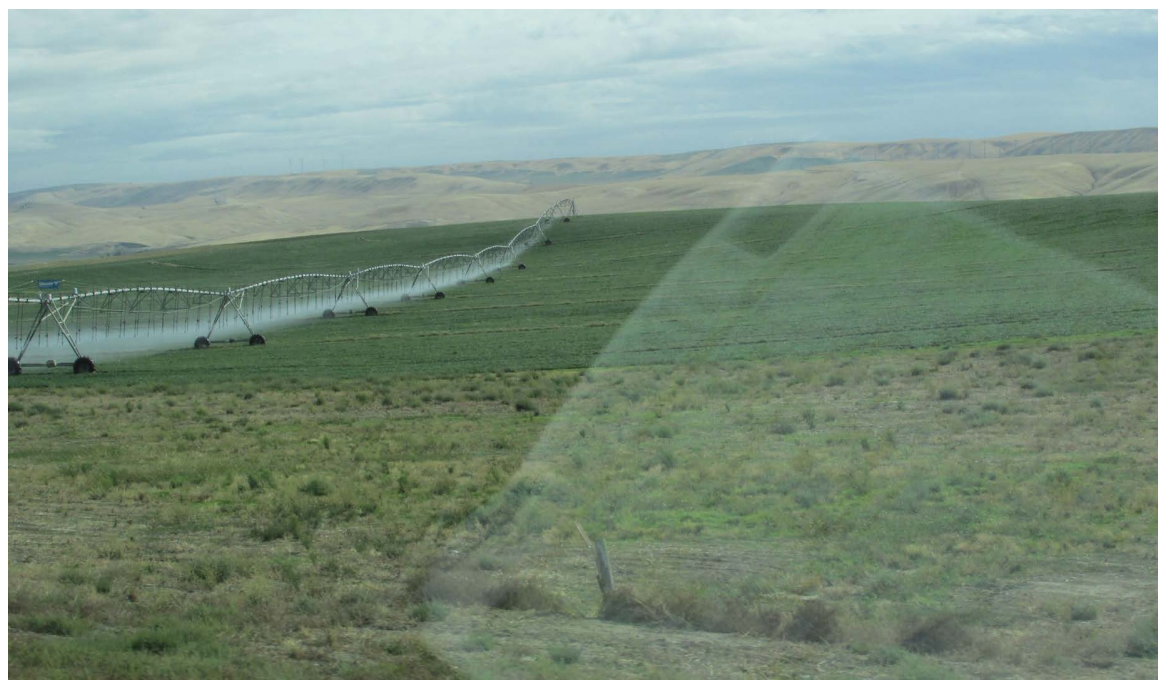

Figure 33. Irrigation equipment in use in the Snake River Valley.

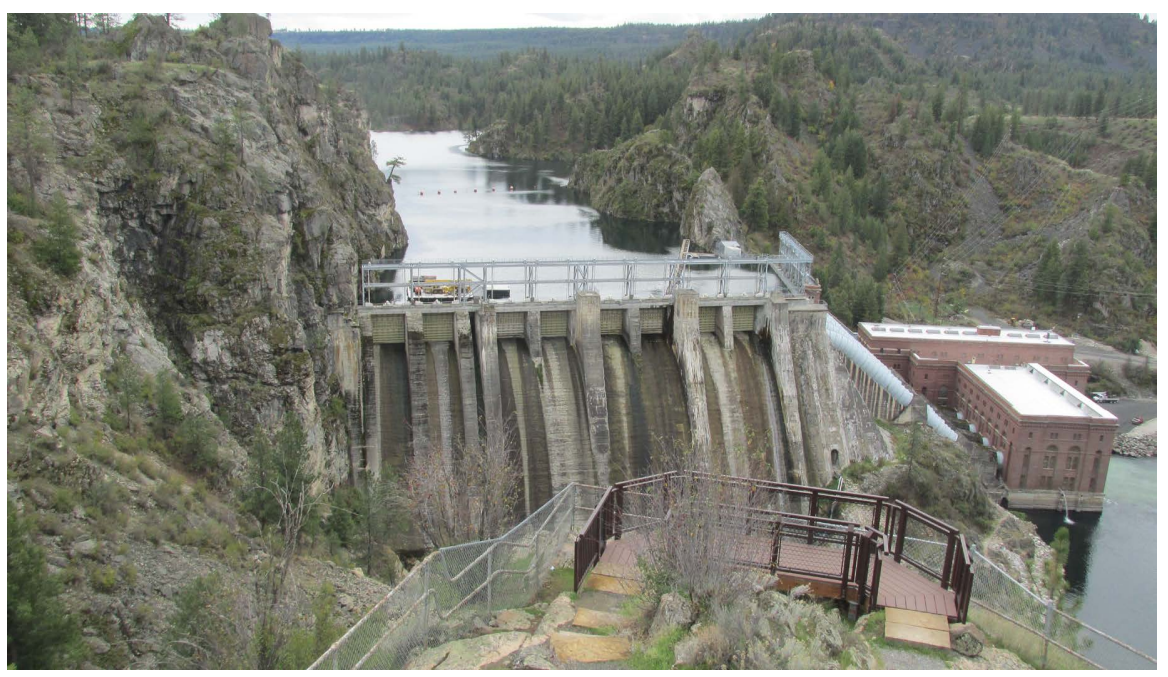

Figure 34. A hydroelectric dam and falls on a tributary of the Columbia River. Photograph by Lois Wright Morton.

the four dams on the Snake River since it would create a hole in the energy grid that could not immediately be filled. Navigation on the Lower Snake River would also suffer, as submerged riffles, rapids and islands would be exposed. In southeastern Washington, irrigation pumps would also have to pump the Snake River water greater distances. In addition to arguing for restoring salmon runs the dam removal proponents argue that the power is replaceable, that only one of the four reservoirs supplies irrigation water and that the grain transportation system could be replaced by railroads.

A letter of concern [11] dated March 26, 2021 was signed by a broad coalition of ports, more than 40 agricultural groups, and other river stakeholders along the Columbia/Snake River system (Figure 1) are opposing the plan to breach four Snake River dams. The plan to protect spawning salmon was proposed by Rep. Mike Simpson of Idaho and includes compensation for farmers and others that would be hurt by the plan. The letter claims that the plan would do little to 


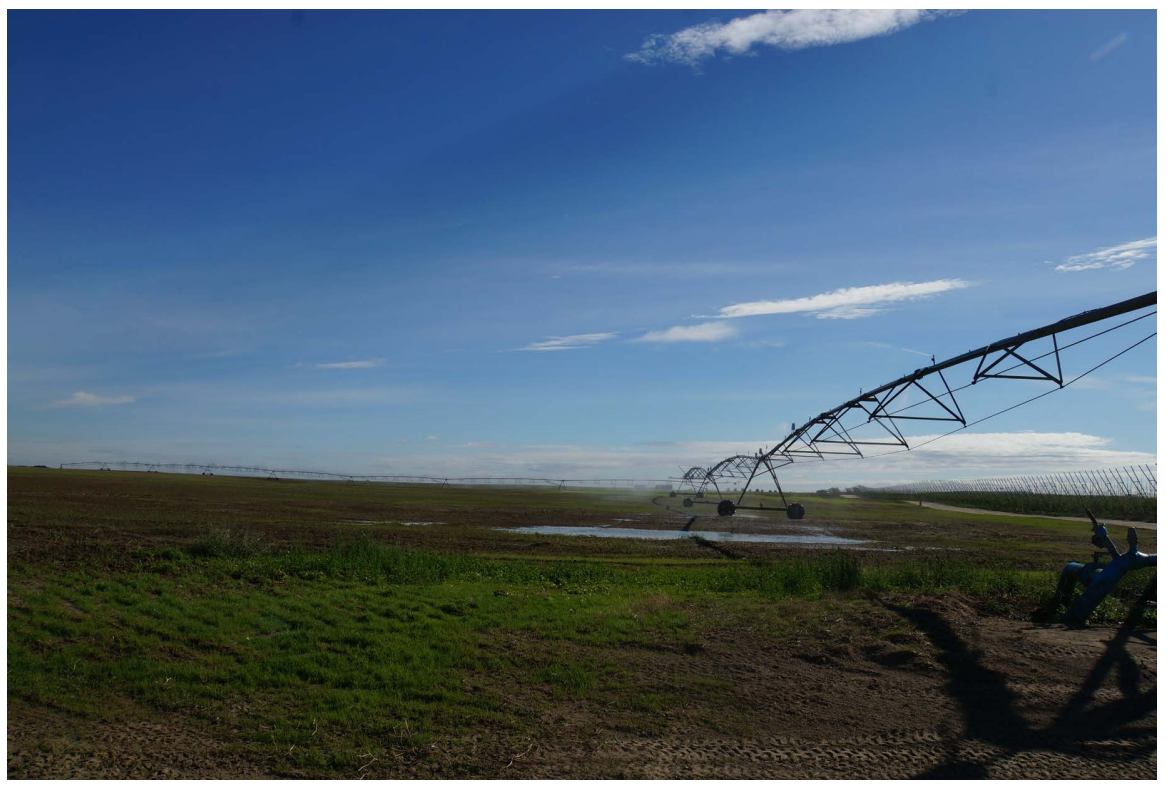

Figure 35. Large irrigation systems along the Snake River just east of the confluence with the Columbia River.

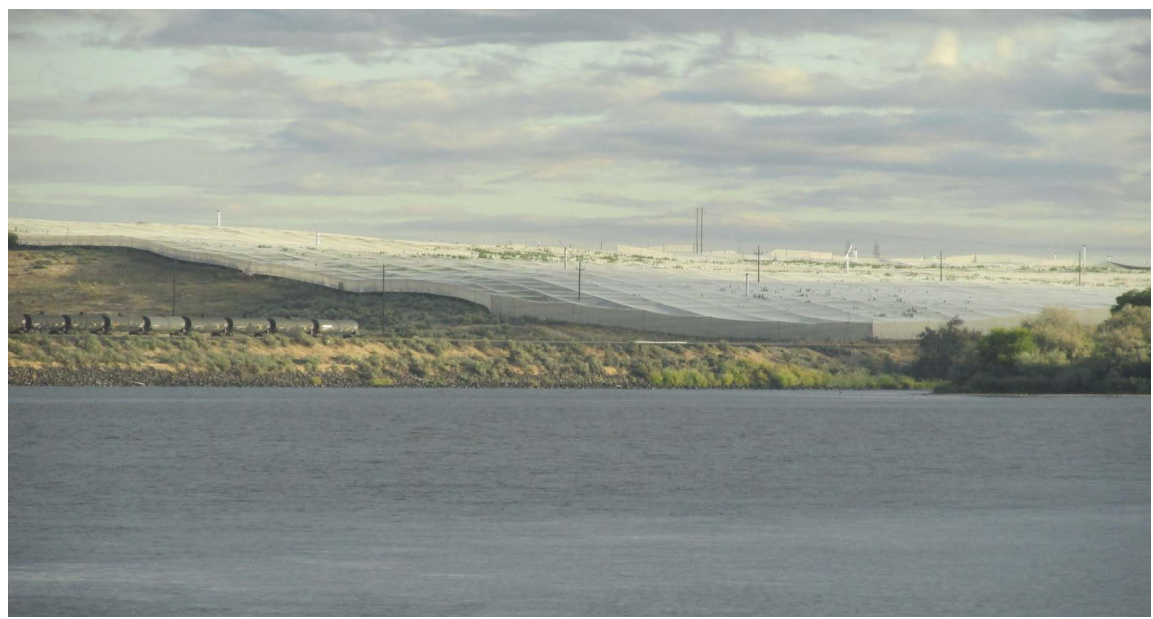

Figure 36. Irrigation equipment under a net adjacent to the Snake River.

protect salmon while it would devastate wheat growers and other agricultural interests in the region that depend on cheap barge transportation. According to the Simpson plan, the breaching of the first dam, the Lower Granite Dam, would happen in 2030. Little Goose, Ice Harbor, and Lower Monumental dams (Figure 31 ) and (Figure 32) would follow the next year. The $\$ 33$ billion plan would disrupt the entire regional transportation structure. Much of the money would go to compensate farmers harmed by the closures. The Pacific Northwest states of Oregon, Washington, Idaho and parts of Montana grow wheat for export to 20 Asia Pacific Rim nations and other places. According to United States Wheat Associates, see letter of concern [11], a wheat-export marketing organization, and all United States farmers, including those in the Great Plains produce about 1.9 billion bushels of wheat a year, which would fill 5000 Panama Canal 
Zone-sized ships [12] a year. In the Pacific North West travel by barge on the Snake River accounts for nearly $10 \%$ of U.S. wheat exports.

The Bonneville Power Administration has pointed out that dam removal could cost the region $\$ 16$ billion to replace power generated at the dams over a 20 -year span using clean energy. Replacing the emissions-free hydropower with other sustainable and emission-free sources could raise electricity rates by 50 percent, and the electricity bills of average, public customer could increase by 25 percent. An additional environmental impact would be the "brown" effect of lock and dam closures which would increase emission by rail and trucks. Over 149,000 semi-trucks or 38,000 rail cars would be needed to move cargo which in addition to wheat, includes fuel products, fertilizer, wood products and large industrial components like wind turbine parts that previously went by barge in 2018. This assumes that many drivers, trucks, rail cars, and locomotives could be sourced, and highway and rail lines through the sensitive airshed of the Columbia River Gorge could be accommodate the additional traffic. The environmental impact of the dam breaching and shifting of cargo from barges to rail and trucks would result in significant annual increases in emissions. According to the letter of concern [11] the emission would total over 860,000 tons of $\mathrm{CO}_{2}, 7.5$ tons of $\mathrm{PM}$ (particulate matter), 69.7 tons of $\mathrm{CO}$ (carbon monoxide), 306 tons of $\mathrm{NO}_{\mathrm{x}}$, and 7 tons of VOC (volatile organic compound).

The letter [11] concludes that 40 pro-dam associations lead by the Association of Wheat Growers "strongly support science-based salmon recovery solutions that address the myriad threats to Northwest fish runs over every part of their life cycle. Though we do not question Rep. Simpson's commitment to salmon, this proposal continues the narrow focus on four runoff-river dams with some of the highest fish passage numbers in our region. It is a speculative and costly plan that assumes we must choose between productive, fish-friendly federal projects and our Northwest salmon and steelhead runs".

\subsection{Pollution of the Snake River}

Throughout the 20th century agricultural runoff from ranches and farms in the Snake River Plain [13] and many other areas has severely damaged the ecology of the river. In the first decade of the 20th century after the first irrigation dams on the river began to operate much of the arable land within a few kilometers wide zone along the Snake River was cultivated or turned into pastureland. The Snake River became polluted by agricultural return water flows. Runoff from several feedlots was dumped into the river until laws made the practice illegal. Fertilizers, manure and other pollutants and chemicals washed into the river greatly increasing nutrient load, especially of fecal coliforms, phosphorus, and nitrogen. During low water, algae blooms depleted the rivers oxygen supply [13]. The Milner Dam and other dams divert water from the Snake River for irrigation, which causes many of the pollution problems in the Snake.

Much of the return flows do not go directly back into the Snake River, but, rather, feed the Snake River Aquifer underneath the Snake River Plain (Figure 
13) and (Figure 14). After absorbing any surface pollutants, the water diverted from the river for irrigation re-enters the ground and feeds the aquifer. Although the aquifer has maintained its level, it has become increasingly laced with contaminants. Water in the aquiferre-enters the river as springs and eventually travels to the west side of the Snake River Plain. Throughout much of the Snake River Plain and Hells Canyon, excessive sediment is also a recurring problem. In December 2007, the U.S. Environmental Protection Agency (EPA) issued an order requiring owners of fish farms along the Snake River to reduce, by $40 \%$, their phosphorus discharge. Pollutant levels, including that of dissolved nutrients, water temperature, and sediment, are required to meet certain Snake River standards, in Hells Canyon (Figure 13) upstream of the Salmon River confluence.

\section{Conclusion}

The movement of the Farallon Plate under the North American plate created a hot spot with volcanic eruptions and lava flows that changed the course of the Snake River. The Bonneville Flood, the first of the major Ice Age flooding events eroded soils and scored the underlying basalt bedrock creating the Snake River Canyon and the widened Hells Canyon. The flood waters deposited huge amounts of sediment in the middle Snake River, and created and re-charged the unique Snake River Aquifer, which is used currently to irrigate farmland in the Snake River bottomlands. These erosional events created the Snake River and the passageway to the West. Without this Snake River passageway, the U.S. settlement of the Northwest would not have happened and the region may have become part of Canada. Below the Shoshone Falls, the Lower Snake River supported salmon runs prior to European and American settlement. Since the late $20^{\text {th }}$ century, the four lower Snake River dams have created a controversy. The wheat farmer needed cheap river transportation and settlers needed a source of electricial energy so dams were placed on the Lower Snake River. However, the creation of the dams, some without fish ladders, and over fishing for canneries, drastically reduced both fish spawning and fish populations.

\section{Acknowledgements}

Published with funding support from USDA, NIFA, Water Division and the Director of the Illinois Office of Research, College of Agricultural, Consumer, and Environmental Science, University of Illinois, Urbana, Illinois.

\section{Conflicts of Interest}

The authors declare no conflicts of interest regarding the publication of this paper.

\section{References}

[1] Olson, K.R. and Suski, C.D. (2021) Food Security: Impact of European Settlement 
and Infrastructure on Columbia River Salmon and Steelhead Migration. Open Journal of Soil Science, 11, 367-388. https://doi.org/10.4236/ojss.2021.117019

[2] Bishop, E.M. (2003) In Search of Ancient Oregon: A Geological and Natural History. Timber Press, Portland Oregon.

[3] Carrey, J. (1979) Snake River of Hells Canyon. Backeddy Books, Boise, 32-42.

[4] Boyd, R. (1996) People of the Dalles: The Indians of Wascopam Mission. University of Nebraska Press, Lincoln.

[5] World Wide Fund for Nature (2021) World Wildlife Fund. https://www.worldwildlife.org

[6] Madsen, B.D. (1980) The Northern Shoshoni. Caxton Press, Caldwell, 18-19.

[7] Madsen, B.D. (1996) The Bannock of Idaho. University of Idaho Press, Nampa, p. 20.

[8] Moulton, G.E. (2003) The Lewis and Clark Journals: An American Epic of Discovery. University of Nebraska Press, Lincoln.

[9] Gulick, B. (2004) Steamboats on Northwest Rivers. Caxton Press, Caldwell, p. 40.

[10] Murray, D. (2021) Fight over Infrastructure Proposal Begins. The Waterways Journal, 135, 3-8.

[11] Washington Association of Wheat Growers (2021) Coalition Letter Supporting Dams Goes Out to Regional Legislators.

https://www.wawg.org/coalition-letter-supporting-dams-goes-out-to-regional-legisl ators/

[12] Olson, K.R. and Tornoe, D. (2021) Long-Term Environmental Impacts of Pesticide and Herbicide Use in Panama Canal Zone. Open Journal of Soil Science, 11, 403-414. https://doi.org/10.4236/ojss.2021.119021

[13] Ritter, W.F. and Shirmohammadi, A. (2001) Agricultural Nonpoint Source Pollution: Watershed Management and Hydrology. CRC Press, Boca Raton, p. 170. 